his environment (ICOM Statutes, 1987:3).

The inclusion of a reference to society's development places an important emphasis on the potential for change. Museums as repositories of art and artifact evidence this same contradiction between stasis and change. Raymond Williams offers three interpretations of the arts:

Either the arts are passively dependent on social reality, a propostion which I take to be that of mechanical materialism ... or the arts, as creators of consciousness, determine social reality, the proposition which the Romantic poets sometimes advanced. Or finally, the arts, while ultimately dependent, with everything else, on the real economic structure, operate in part to reflect this structure and its consequent reality, and in part, by affecting attitudes towards reality, to help or hinder the constant business of changing it (williams, 1958:266).

It is not surprising that these same tensions between cultural orthodoxy and cultural innovation, and the social/economic mechanisms which activate them, exist between and within institutions of art a.ld artifact. The National Gallery of Canada, for example, displays both historical art and recent videos. Visitors, staff and volunteers are attracted to the fallery for various reasons. It is possible to engage those interested in cuntemporary Canadian video artist Richard Fung and also those interested by 19 th century Quebec artist Joseph Legare, because the Gallery collects, exhibits and interprets the work of both.

Both national museums and non-federal museums (provincial museums, art galleries, community historical museums, etc.) share an historical backdrop of policy 
D.t. National Library

Canadian Theses Service

\section{Biblıothèque nationale}

du Canada

Ottawa, Canada

K1A Oria

\section{Service des theses canadiennes}

\section{NOTICE}

The quality of this microform is heavily dependent upon the quality of the original thesis submitted for micrcfilming. Every effort has been made to ensure the highest quality of reproduction possible

if pages are missing, contact the university which granted the degree.

Some pages may have indistinct print especially if the original pages were typed with a poor typewriter ribbon or if the university sent us an inferior photocopy.

Reproduction in full or in part of this microform is governed by the Canadian Copyright Act, R S C. 1970, C. C-30, and subsequent amendments.

\section{AVIS}

La qualtté de cette microlorme dépend grandement de la qualıte de la thèse soumise au microfilmage Nous avori: rout lail pour assurer une qualıté supérıure de reproduc tion

Sill manque des pages, veullez communiquer aver l'université qur a contéré le grade

La qualité dimpression de certairies pages peut lassrer a désirer, surtout sı les pages originales ont été dactylogr a phiées à l'arde d'un ruban usé ou sı l'universite nous a fidi parvenir une photocopie de qualité intérieure

La reproduction, méme panuelle, de celte nicrolorme er.t soumise à la loo canadienne sur le dront d'auteur. SHA. 1970. c C.30. et ses amendements subséquents 
MUSEUM POLICY, MUSEUM PRACTICES AND CULTURAL CHANGE

\author{
by \\ Laurence Grant, B.A. \\ A thesis submitted to \\ the Faculty of Graduate Studies and Research \\ in partial fulfilment of \\ the requirements for the degree of \\ Master of Arts \\ Department of Sociology and Anthropology \\ Carleton University
ottawa, Ontario
November 22,1991
O copyright
1991 , Laurence Grant
}


Cinadian Theses Service Service des thises canadiennes

Otlana. Canada

KIA ONA

The author has granted an irrevocable nonexclusive licence allowing the National Library of Canada to reproduce, ban, distribute or sell copies of his/her thesis by any means and in any form or format, making this thesis available to interested persons.

The author retains ownership of the copyright in his/her thesis. Neither the thesis nor substantial extracts from it may be printed or otherwise reproduced without his/her permission.
L'auteur a accordé une licence irrévocable et non exclusive permettant à la Bibliothèque nationale du Canada de reproduire, preter. distribuer ou vendre des coples de sa these de quelque manière et sous quelque forme que ce soit pour mettre des exemplaires de cette thèse à la disposition des personnes intéressées.

L'auteur conserve la propriété du droit d'auteur qui protège sa thèse. Ni la thèse ni des extraits substantiels de celle-ci ne doivent être imprimés ou autrement reproduits sans son autorisation. 
The undersigned recommend to the Faculty of Graduate studies and Research acceptance of the thesis

MUSEUM POLICY, MUSEUM PRACTICES AND CULTURAL CHANGE submitted by Laurence Grant, B.A.

in partial fulfilment of the requirements for the degree of Master of Arts

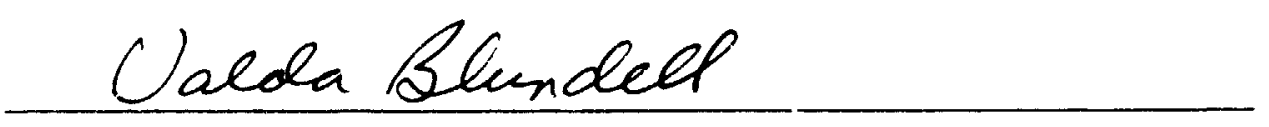

Thesis Supervisor

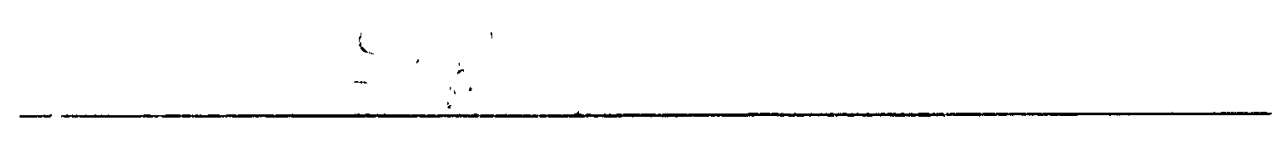

Chair, Department of Sociology and Anthropology

Carleton University

November 22,199 ? 


\section{ABSTRACT}

This thesis explores the relationship between Canadian museum policy, museum practices and cultural change. Federal museum policy of the last fifty years is reviewed as a backdrop for understanding current museum policy and practices. Two case studies, both at the National Gallery of Canada, are analyzed for their implications for cultural homeostasis and cultural change. Antonio Gramsci's concept of hegemony is used to facilitate an understanding of how the practices of the National Gallery support a prevailing hegemony while simultaneously offering counter-heqemonic meanings. Victor Turner's concept of liminality permits an understanding of how cultural experimentation and cultural change occur within the ritual space of this same federal institution. 
ACKNOWLEDGEMENTS

Frequently in the course of thinking about the museum matters that receive discussion within these pages, my thoughts (pensees) have turned to Jacqueline Fry, who initiated my relationship to museums in Montreal in the mid 1970s. Jacqueline died this past summer.

Once all was said and possibly done, Graeme Davies was resourcefully there to give form to the substance. I'll not forget the delight of steing pages with "correct" margins, spacing and numbering being produced by a printer as lunch awaited.

Valda Blundell sustained my sometimes faltering belief that it would be possible to think and write my way to useful text. This experience has, in the end, left me thinking while I work. 
Table of Contents

Page

Acceptance Sheet

Abstract

Acknowledgements

Table of Contents

Chapter 1

Introduction 1

Chapter 2

Historical Directions of Federal Museum Policy 9

Introduction 9

1932: The Miers-Markham Report 11

1951: The Massey-Levesque Report 16

1972: The National Museum Policy 22

1982: The Applebaum-Hebert Report 31

1985/86: The Nielsen Review 38

1986: Richard withrow Report 42

1986: The Bovey Report 47

1988: Challenges and Choices 49

Conclusions 61

Chapter 3

The Role and Influence of Docents in the National

Gallery of Canada

A Brief History of the Art Museum Docent 70

The Developmer t of Docentry in Canada 73

The Conception of Art and its Utility as a

Status Marker $\quad 74$

The Social Context of Museum and Docent Work 77

The Training and Work of Docents 83

Chapter 4

The National Gallery Video Room: A Culturally

Transformative Space

Victor Turner and Liminal Phenomena 97

Video at the National Gallery of Canada 101

Richard Fung's "Chinese Characters" 104

The Controversy 108

Analysis of Controversy 112

Conclusion $\quad 120$

Chapter 5

$\begin{array}{ll}\text { Conclusions } & 124\end{array}$

$\begin{array}{ll}\text { References } & 129\end{array}$ 
MUSEUM POLICY, MUSEUM PRACTICES AND CULTURAL CHANGE

CHAPTER 1

\section{INTRODUCTION}

Museums can be sites of cultural orthodoxy and they can be sites of cultural innovation. Often these two

possibilities are in tension with one another. Indeed, this tension exists even within the varying definitions of the museum as an institution. That of the ontario Ministry of Culture and Communications, for example, emphasizes past culture, defining a museum as

an institution that is established for the purpose of acquiring, conserving, studying, interpreting, assembling and exhibiting to the public for its instruction and enjoyment a collecticn of artifacts of historical interest (Ministry of Culture and Communications, 1983b:2).

That same Ministry's museums policy further describes

museums as

repositories of our collective memory, preserving and presenting the rich and varied material culture of the past for our education and enjoyment (Ministry of culture and communications, 1983a:2).

The International Council of Museums, on the other

hand, defines museums as

any nnn-profit, permanent institution in the service of society and its development, which is open to the public and acquires, conserves, researches, communicates and exhibits, for the purpose of study, education and enjoyment, material evidence of man and his environment (ICOM Statutes, 1987:3). 
his environment (ICOM Statutes, 1987:3).

The inclusion of a reference to society's development places an important emphasis on the potential for change. Museums as repositories of art and artifact evidence this same contradiction between stasis and change. Raymond williams offers three interpretations of the arts:

Either the arts are passively dependent on social reality, a propostion which I take to be that of mechanical materialism ... or the arts, as creators of consciousness, determine social reality, the proposition which the Romantic poets sometimes advanced. Or finally, the arts, while ultimately dependent, with everything else, on the real economic structure, operate in part to reflect this structure and its consequent reality, and in part, by affecting attitudes towards reality, to help or hinder the constant business of changing it (williams, 1958:266).

It is not surprising that these same tensions between cultural orthodoxy and cultural innovation, and the social/economic mechanisms which activate them, exist between and within institutions of art and artifact. The National Gallery of Canada, for example, displays both historical art and recent videos. Visitors, staff and volunteers are attracted to the callery for various reasons. It is possible to engage those interested in cuntemporary Canadian video artist Richard Fung and also those interested by 19th certury Quebec artist Joseph Legare, because the Gallery collects, exhibits and interprets the work of both.

Both national museums and non-federal museums (provincial museums, art galleries, community historical museums, etc.) share an historical backdrop of policy 
government, provincial governments or municipal governments. Museum policy can set objectives for a particular level of government, its agencies and clients, and delineate how, through the mechanism of funding, these objectives will be encouraged. Such museum policies ultimately have some influence on individual museum practices. They too can emphasize the culturally orthodox, and/or permit museums to be sites of cultural variability and change, even of fering counter-hegemonic meanings and understandings. Such a contrast in roles has the implication that museums and museum policies will be sites/foci of contestation. An examination of federal museum policies and the manner of their formation thus facilitates an understanding of competing views on the part of various groups in Canada of the objectives of policy. Such an examination also permits insights into attempts of the state to manage different views.

In this thesis I will consider to what degree fecieral museum policy in Canada influences museum practices in possibly effecting/restricting social change, and in particular, I will examine through two case studies how this has actually occurred. A history of federal museum policy will be traced in Chapter 2, beginning with the MiersMarkham Report of the 1930 s and ending with the Canadian Museum Policy of 1990. The increasing involvement of such non-government organizations as the Canadian Museums 
Association, in policy making discussions, will also receive attention.

I will consider in Chapters 3 and 4 , two case studies within the context of a federal museum. The first case study involves the work of volunteers at the National Gallery of Canada. With reference to the work of Antonio Gramsci (as interpreted by Tony Bennett), I will consider the role of the art museum volunteer in maintaining a certain control of the National Gallery. Volunteers will be seen to socially benefit by their association with the Gallery through the powerful legitimizing means conveyed by this association. They are able, through the seemingly altruisitic gesture of volunteering, of doing good works, to exert a proprietary influence over a theoretically public institution. The development of art museum volunteerism, or docentry, will be discussed and parallels drawn with other major North Americ?n art museums. Art museum volunteers will be viewed as constituent elements of a hegemonic class that use the symbolic form of art within the hegemonic apparatus of the art gallery as part of the "cement" for maintaining their hegemonic relations. Hegemonic class is understood here as one which "has been able to articulate the interests of other social groups to its own by means of ideological strugglen (Mouffe in Bennett, et. al., 1981:223). Dominance of one social group over another is 
maintained, according to Gramsci, by the cultivation of

consent:

Undoubtedly the fact of hegemcny presupposes that account be taken of the interests and the tendencies of the groups over which hegemony is to be exercised, and that a certain compromise equilibrium should be formed - in other words, that the leading should make sacrifices of an economic- corporate kind (Gramsci in Bennett, et. al., 1981:197).

This is accomplished within the context of the state,

which Gramsci defines as

the entire complex of practical and theoretical activities with which the ruling class not only justifies and maintains its dominance, but manages to win the active consent over whom it rules (Gramsci in Bennett, et. al., 1981:216).

Although Gramsci doesn't make specific reference to museums as hegemonic apparatuses, he does refer to schools, churches, the media and architecture in that light. Given the educative function of museums, they clearly can be argued as forming part of the structure of hegemony. Art museums such as the National Gallery, it will be argued, contain "high" culture (meaning culture where aesthetic forms are privileged as opposed to the anthropological understanding of culture as a way of life) that forms part of the ideological unity of a dominant class. Conversely, the "highness" of this culture is transformed into a "popular belief" that results in prestige for the dominant group, keeping leaders and led together in hegemonic relations. 
A countervailing influence on the National Gallery will be examined in chapter 4 through a second case study. The controversial video programming with which the Gallery opened in 1988, permits an analysis of this institution as a site of contradictory and contested purposes, as a multivocal symbol (Turner, 1974:28). This contrasting and counterbalancing conception of the Gallery's role permits a reconsideration of the insticution according to the formulations of the anthropologist victor Turner, as a potential storehouse of cultural alternatives and facilitator of cultural innovation and cr.ange. Turner saw that such change could occur during liminal moments. He borrowed the term from the anthropologist Van Gennep and his description of rites of passage, in order to describe transitional phenomena. During such momencs, social process is uprooted from the customary cultural constraints as passage to another category of life and experience occurs. This release fr.om the customary made possible

the deconstruction of the 'uninteresting' constructions of common sense.... into cultural units which may then be reconstructed in novel ways... (Turner, 1985:160).

In small scale societies, Turner viewed liminality as providing the cultural means of producing variability in addition to assuring continuity. To him, liminality formed part of an adaptive strategy that, through the maintenance of a repertoire of alternatives, enabled a society to possibly overcome drastic ecological or social change. When 
Turner adjusts his analysis to a consideration of complex urban socifties, he prefers the term "liminoid". There he viewed the arts, broadly defined, as providing the opportunity for cultural alternatives to be perceived and experimented with. Museums, through their presentation of art and artifact, I maintain, can provide the locus of such cultural experimentation.

Gramsci also considered how the process of cultural change occurred. He saw workers as having what he called two contradictory "theoretical consciousnesses":

one which is implicit in his activity and which in reality unites him with all his fellow-workers in the practical transformation of the real world: and one, superficially explicit or verbal, which he has inherited from the past and uncritically absorbed (Gramsci in Bennett, et. al., 1981:204).

Political and moral passivity reigned until the moment that a seli-awareness arose, first in ethics and then in politics, of being part of a hegemonic force:

Thus the theory of unity and practice is not just a mechanical fact, but a part of the historical process, whose elementary and primitive phase is to be found in the sense of being 'different' and 'apart', in an instinctive feeling of independence, and which progresses to the level of real possession of a single and coherent conception of the world (cited in Bennett, et. al., 1981: 205).

Real change became possible once this sense of selfawareness became transformed into criticism:

Having first shown that everyone is a philosopher, .... one then moves on to the second level, which is that of awareness and criticism. ... is it better to take part in a conception of the world mechanically imposed by 
the external environment, i.e. by one of the many social groups in which everyone is automatically involved from the moment of entry into the conscious world...? Or, on the other hand, is it better to work out consciously and critically one's own conception of the world...? (cited in Bennett, et. al., $1981: 205-206)$.

Cultural change and the creation of new culture was a

social process:

Creating a new culture does not only mean one's own individual 'original' discoveries. It also, and most importantly, means the diffusion in a critical form of truths already discovered, their 'socialization' as it were, and even making them the vital basis of action, an element of co-ordination and intellectual and moral order (Gramsci in Bennett, et. al., 1981:206).

Such a process he considered to be gradual and led to the creation of a new hegemony through a "rearticulation of existing ideological elements" (Mouffe in Bennett, et. al., 1981:230). Mouffe refers to this process as one of "disarticulation - rearticulation (p. 231). It will be argued that the video room at the National Gallery provides the opportunity for the disarticulation of an hegemonic structure through not only the subversive content of the videos, but also the confusion over whether videos are art (high art or low art). The Gallery will be considered as a locus for the potential rearticulation of a new world-view. Gramsci thus provides an essential understanding of social stratification and social conflict and how these may become rearticulated in new cultural forms that is lacking in Turner's more liberal idealist analysis. 
CHAPTER 2

HISTORICAL DIRECTIONS OF FEDERAL MUSEUM POLICY INTRODUCTION

This chapter provides an historical analysis of federal museum policies in Canada. The national policy background against which all Canadian museums operate directly influences a national museum such as the National Gallery of Canada and can influence even small local museums. There is the opportunity, at the federal level, of using policy to maintain cultural homeostasis and/or to create the opportunity for cultural change through permitting the development of potentially counter-hegemonic forces. The degree to which this occurs in practice will be examined through the case studies in chapters 3 and 4 . Chapter 3 will view the Naicional Gallery from the perspective of a prestigious hegemonic apparatus of the state where art museum volunteers will be viewed as exerting a proprietary influence over the Gallery and its symbolic content. This will be contrasted in chapter 4 with the culturally transformative function of this same institution. An exhibition of contemporary Canadian videos challenges, it will be argued, dominant class views of both sexuality and the appropriate role for the National Gallery within the state. The contradiction between these two functions can in part be understood through reference to federal museum 
policy and the principle of arm's length funding. Federal policy has permitted the growth of such arm's length agencies as the Canada Council and institutions such as the National Gallery, which operate without daily administrative reference to the federal government.

In what follows, I will trace the rise and fall of the federal policy of establishing arm's length agencies. I will also describe other federal policy themes and their relationship to shifting conceptions of the utility of museums and in turn their relationship to the changing nature of, in Gramsci's terms, cultivating consent. The federal government also, in the 1970s, began providing financial support to such non-government organizations as the Canadian Museums Association. This, it will be argued, gave museums a greater voice in the hegemonic order and gave greater voice to demands for federal government support for non-federal museums. Such practices, however, seem to be fading with recent changes in federal museum policy.

A complete history of cultural policy in Canada can never be told through reference to a series of policy texts. Cultural policy can result as much from inaction by government as from specific textual recommendations for action. Nonetheless, policy texts do become key markers in the understanding of ideals, objectives and patterns in policy making. It is principally this use that has led to this particular consideration of museum policy texts from 
the 1930s to the 1990s. Comprehensive cultural policies have been attempted in Canadian history, but not realized. Given the jurisdictional vagueness of culture (it was not mentioned in the British North America Act of 1867) and the diversity of meanings ascribed to culture, it is no wonder that a comprehensive policy has not been achieved. As in so many aspects of complex societies, a division of labour inevitably compartmentalizes human activity and experience. A cultural worker can be a dancer, a museum employee, a government policy worker, a visual artist. The separateness of activity creates a separateness of policy making. It is at times an arbitrary convenience, at other times an arbitrary tyranny.

The culiural subdivision that is the subject of this chapter is federal policy making as it relates to Canadian museums. The discussion begins in 1932 with a report that is not, by the way, a federal government policy document.

\section{2: THE MIERS-MARKHAM REPORT}

Support for the first report on the state of Canadian museums came through a force external to the country - the Carnegie Corporation of New York. This report followed a similar one produced on the museums of Great Britain, and was preliminary to possible Carnegie support for Canadian museums (Teather, 1978:27). The authors Henry A. Miers and S. F. Markham describe their report as being 
divided into two sections, the first giving the picture of the situation in Canada as we saw it, the second part comparing this with the museum movement elsewhere, and offering suggestions as to its improvement (Miers and Markham, 1932:v).

As such, the report had no particular government sanction, nor was there a jovernment response.

The report chronicled the sorry state of Canadian museums in 1932. Apart from museums in Toronto (Royal Ontario Museum), ottawa (National Museum and National Gallery), Montreal (Art Association's Gallery and Peter Redpath Museum), Saint John (New Brunswick Museum), Quebec (Musee du Quebec), Vancouver (Art Gallery of Vancouver), Kingston (Miller Building for geology and mineralogy) and Halifax (Public Archives), the authors stated that

most Canadian museums, both in building and equipment, fall far below the average in the remainder of the North American continent... In the main, the average museum in Canada is housed in one or two rooms of a university, college, school, library or government building, scarcely any of which were designed with museum purposes in view ( $p$. 9).

With a minority of museums being the exception, other chapters described the following:

i. Collections:

At smaller institutions it is a positive sir. to collect miscellaneolis objects without any definite purpose.

Many of them seem to have accepted and tried to exhibit everything they are given, with disastrous results... (p. 14).

ii. Staff:

It must be regretfully admitted that only in a score of museums out of 125 is there a competent full-time 
curator, and that in only eight of the score are there adequately qualified museum assistants (p. 24).

\section{iii. Administration and finance:}

Taking Canada as a unit, it is a most extraordinary fact that less is spent on the whole group of 125 museums than is spent on one of the great museums in Great Britain, Germany, or the United States (p. 29).

iv. Co-operation:

A regrettable deficiency in the present museum system in Canada is the absence of any general form of cooperation... (p. 31), ...the local museums are isolated units cut of from the main stream of museum activity, and some form of co-operation between these and larger museums is an imperative and urgent need ( $p$. 35).

v. Museum services to the public:

...very few museums in Canada - especially the Society and School Museums - make any effort to attract or interest the general public...it is made as difficult as possible for any one to $f$ ind the museum, and when found, to be able to see it as it should be seen ( $p$. 39).

vi. Museums and schools:

these [aforementioned] activities only reach a few of the hundreds of thousands of Canadian school children, and the problem that will eventually have to be tackled is how to bring museum services into rural areas. Though this may be partially solved by the establishment of more museums and by bringing children into them from adjacent districts, the bulk of the children of Canada are so far removed from existing or potential museum centres that the solution must be found by other methods ( $p .42$ ).

vii. Research:

So little [research] is done in most of them at present, that there is not much to be said on this head except to express the hope that investigation will come to be regarded as one of the ordinary functions of a museum ( $p$. 43).

Part II of the report of Miers and Markham consists of 
criticisms and suggestions. The report clearly specifies the need for additional funds, but does not specify that these should be provided by the federal government except in the case of federal museums:

It would clearly involve a large outlay to supply good local museums in every town over 30,000 that does not already possess one, and perhaps a still larger expenditure to establish specialized museums... But what is even more urgent and essential is to bring existing museums, especially those in smailer towns, up to a standard of efficiency whereby they can render great public service ( $p .52$ ).

Miers and Markham write of equipment grants, building grants and reorganization grants, putting one in mind of the Museum Assistance Program of the 1970s and 1980s. They make "museum authorities" responsible for providing the funding. Following a British tradition of municipally supported museums, they suggest that

if the local authorities could undertake to nake themselves responsible for half or two-thirds of the total cost of building and to set aside during a definite period a suitable amount for maintenance and salaries they might hope to seek and receive assistance from other sources sufficient to meet the remainder of the cost (p. 49).

These other sources are later referred to as exterior sources. The authors seem to have in mind both the provincial governments and foundations:

The line of greatest progress at the moment can best be followed by developing within each province its own cultural and educational tendencies ( $p .60)$.

Miers and Markham consequently suggest the development of strong regional or provincial museum associations over a national association because of the great distances and 
cultural differences of Canada. They further suggested that such outside bodies as the Rockefeller or Carnegie foundations provide grants for the establishment of secretariats for associations. These associations would facilitate cooperation among museums, an essential feature found to be lacking in Canada.

Another suggested source for supplying cooperation, assistance and advice is provincial government. In this regard, these features are noted:

practically no assistance is at present given by the provincial governments to non-provincial museums; the provincial government is the only body which can hope to provide any such assistance on permanent lines: such a system could only be worked out with the full approval of local museums (p. 61-62).

Provincial authorities are also suggested for providing travel grants for training seminars.

The role of the federal government and federal museums is thought to be problematic. It is suggested that the National Museum develop close working relationships with the central museum in each province. The scheme suggested resembles the 1972 associate museum status:

there should be some sort of affiliation on the part of the dozen provincial museums with the national headquarters at ottawa ( $p .63$ ).

The report of Miers and Markham provides a state of affairs for Canadian museums in the 1930 s and established the beginnings of a referential repertoire for museum policy makers in Canada. Written prior to the period of central state intervention in many aspects of Canadian life (e.g. 
before old age pensions, baby bonuses, health care proqrams, etc.), its recommendations are decentralizing in spirit.

The authors themselves note that

in Great Britain and in the United states, during the last decade, there has been a marked tendency towards what may be termed decentralization (when speaking of museum associations] ( $p$. 60).

In general, the report places responsibility for the provision of financial support to non-federa? museums upon provincial and municipal governments. The federal museums are seen as being the means of federal government intervention. Because of geographic and cultural distance, a centralized government and associational approach is not recommended for Canada.

\section{1: THE MASSEY-LEVESQUE REPORT}

In 1951, the authors of the, "Report of the Royal Commission on National Development in the Arts, Letters and Sciences "(Massey-Levesque Report) looked back at the report of Miers and Markham of twenty years earlier, and made the following observations:

We assume that it was thought that Canadians if informed of this regrettable situation, would take immediate measures to correct it. No such measures were ever taken. We believe that during our own admittedly superficial survey of a matter, which, important as it is, lies only on the periphery of our Terms of Reference, there appeared the first evidence of general public concern for museums since the publication of the Report. Those who compare the record of our own impressions with the findings of the Report will see that the present shows little if any signs of improvement. The annual per capita expenditure on museums in terms of real value has 
probably decreased(p. 99).

The Commission was not specifically mandated to investigate non-federal museums, but nonetheless a descriptive section on local galleries follows that of the National Gallery as does another section on local museums follow that on the National Museum. The federal museum/local museum relationship is viewed as follows:

[The National Gallery] operates therefore not only in ottawa but throughout the country, and to see its work as a whole one must leave the capital and visit the local galleries in the provinces ( $p .81$ ).

There was found to be greater satisfaction with the extension services of the National Gallery and a greater awareness of the importance of its role. The commission received some suggestions that the National Gallery should be decentralized and that branch or affiliated galleries should be located throughout the country:

The exact relations which these should have with the central gallery are not always made clear. One group seems to imply that these branches should be owned by tine Federal Government. Another suggests that an assistant to the curator be supplied by the Federal Government. Most seem to have in mind a gallery, supported by local funds, receiving national pictures on permanent loan. It was submitted that this would encourage cities and towns throughout the country to raise their standards of building curatorship ( $p$. 86).

Generally, there was a growing expectation that the federal government should be providing funds that could be utilized across Canada. The vehicle for this utilization would be the expanded services of the National Gallery:

It is probably true that most organizations would be satisfied if arrangements could be made to finance a 
more extensive exhibition policy. Five national organizations of widely different interests...advocated nation-wide exhibitions, if necessary, at the nation's expense (p. 86).

The services of the National Museum, on the other hand, were thought to be inadequate. One witness is quoted as saying:

The National Museum, I know, is interested in the whole of Canada, but does not seem to be interested in other museums or museums societies...(p. 96).

Although the Massey-Levesque Report observes the situation of museums across canada, its primary focus remains the national institutions. Discussions within the Report demonstrate that there were tensions between federal and non-federal museums regarding the appropriateness of federal government support. There are indications that some non-federal museums envisaged a larger role for the central government. Any recommendations made, however, have the intent of improving the national institutions. Their improvement would have the secondary benefit of assisting non-federal museums. Federal museums thus remain the primary instrument of federal policy. For example, it was recommended:

That the present services of travelling exhibitions organized or sent out by the National Gallery be developed and extended... (p. 315).

and also

That as soon as possible the National Gallery be housed in a new building containing adequate facilities for display, storage, circulation of exhibitions, repair and restoration of paintings, and, in addition, for 
greatly increased extension and education services (p. 316$)$.

with respect to the National Museum, it was recommended:

That the proposed board of trustees place immediate emphasis on educational and information services through loans, travelling exhibits and travelling lecturers: and that special attention be given to information services and advice to small museums throughout the country (p. 322).

and also

That the board of trustees co-operate with other Canadian Museums either through the Canadian Museums' Association or directly to devise a simple and practicable scheme for the training of museum curators (p. 322 ).

No recommendations were made directly implicating nonfederal museums. A major recommendation of the Massey Commission led to the establishment of the Canada Council. Museums and galleries dealing with contemporary art were affected through the programs developed by the council. The relationship is however, indirect and arms's length, that is, government entrusting funds to another authority, but not maintaining direct administrative and intellectual control. With direct control only over the amount of the Council's yearly appropriation, the Canadian state was less able to manage the content of the council's programs. These could take directions quite contrary to the views of the government of the day. Government was thus funding a body that had the potential to culturally challenge the established hegemonic structure.

The Massey Commission thus continued the tradition of 
viewing federal museums as the prime instrument of assistance to other museums, without advocating the specific involvement of other levels of government. It was not mandated to investigate non-federal museums and it does so only to the degree of demonstrating how federal institutions could be of assistance. Federal involvement was viewed as a centralized involvement at a time of increasing central state intervention in social and cultural affairs. It is interesting to note the justification for Eederal involvement found in the terms of reference of the Commission. It involves that long standing Canadian preoccupation with national identity:

That it is desirable that the Canadian people should know as much as possible about their country, its history and traditions; and about their national life and common achievements;

That it is in the national interest to give encouragement to institutions which express national feeling, promote common understanding and add to the variety and richness of Canadian life, rural as well as urban... (p. xi).

A political justification is thus added to what is considered the already self-evident value of the enlightenment and delectation provided by the arts, which, to paraphrase, enrich the mind and refine the taste (p. 7). This is in strong contrast to the recommendation that led to the development of the Canada council. Here the Massey Commission was fulfilling a more orthodox function of supporting national unity. The commission thus can be viewed as seeing museums in the elitist sense of developing 
refinement. They were to be forces of education in Canadian life, a patriotic binding force that was "in the national interest". Gramsci viewed patriotism as one of the binding forces of hegemony:

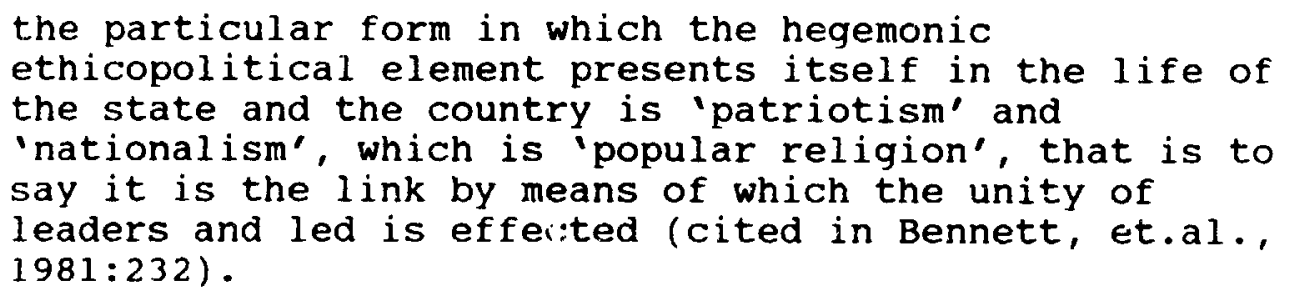

The Massey Commission thus saw museums as a component of a Canadian ideological unity that would "promote common understanding" in a country faced with internal linguistic and political divisions. National museums and other national cultural organizations would, following Gramsci's analysis, constitute national hegemonic apparatuses, the whole of which would form an important constituent element of the ideological structure of the hegemonic class and contribute to its prestige:

...the most reasonable and concrete thing that can be said about the ethical state, the cultural state, is this: every state is ethical in as much as one of its most important functions is to raise the great mass of the population to a particular cultural and moral level, a level (or type) which corresponds to the needs of the productive forces for development, and hence to the interests of the ruling classes (cited in Bennett, et. al., 1981:216).

The cultural institutions of a society are thus a crucial element in the education of consent, for hegemony is not only economic, it is also "ethical-political". 
1972: THE NATIONAL MUSEUM POLICY

With the National Museum Policy of 1972 we see the most dramatic departure from previnus policies and practices. The new policy was never published as a discreet text, but was disclosed in a series of speeches. First announced by federal secretary of state Gerard Pelletier in a speech in Calgary (and later printed in Gazette [Pelletier, 1972] the journal of the Canadian Museums Association), it was overtly decentralist. There were, according to Pelletier, two overall objectives to this policy: democratization and decentralization.

Democratization he defined as,

increasing access to the products of cultural activity for all taxpayers, not only a select group as has been the case in the past. Since this concerns the use of public funds, it would be unfair to promote cultural activities that are reserved for the happy few ( $p$. 4).

Decentralization is described as,

an active battle against vast distances in order to make our cultural symbols available to all Canadians, no matter where they live (p. 4).

Pelletier goes on to describe the past federal record:

We decided to give priority to reviewing our policy on museums partly because the activities of the federal government in this connection are the most highly centralized and least accessible to Canadians as a whole ( $\mathrm{p} .4$ ).

Pelletier speaks of the impossibility of isolating museum policy from the, "larger more complex reality", of cultural policy. He nonetheless does. Administrative traditions develop and institutional manifestations are 
their product.

Pelletier justifies government action in this field becausı, "government is the contemporary patron of the arts" :

It is a fact that governments of the western world, without exception, support certain cultural activities which could not otherwise survive. Even the United States, who has for so long been bound to the tradition of private initiative, is beginning to support cultural activity with public funds. The pertinent question in this field is not whether canada has the means to sustain cultural activity. It is rather does government have the means to refuse its support (p. 4).

Pelletier had previously, at consultation conferences with museum personnel leading to the new policy developments, elaborated on other principles than democratization and decentralization. These were pluralism, federal-provincial cooperation and international liaison. Pelletier affirmed that new structures would be required in order to implement the new principles and an injection of funds would be required for these structures. Previous federal governments had limited their activities to developing the national museums (with the exception of special grants available for the marking of the Centennial of Confederation). The Canada Council had given some minor assistance to some museuns outside ottawa. Pelletier in 1972 practically doubled the budget of the National Museums Corporation (an arm's length body created in 1968 to provide a common administrative structure for the national museums) 
from $\$ 10$ million in 1971 to $\$ 19.5$ million. The additional

funds were to be allocated to the new programs, which, according to Pelletier (1972), included:

-the creation of a network of associate museums in order to "even out existing disparities as regards museum collections, activities and standards" (p. 5).

-the creation of a, "network of National Exhibition Centres, which would complete and extend their (associate museums) action. Such centres generally, "will not have their own collections, but will devote their efforts to using travelling exhibitions and displays from the associate museums..." (p. 6).

-the creation of a "National Loan Collection, to be separate from the museums framework. It is designed to reach the public outside of museums, be that at Shopping centres or public buildings... Thus isolated areas and locations which are unsuitable to receive exhibition material will be able to share in Canada's cultural heritage" (p. 6 ).

-the establishment of a fleet of mobile exhibits - "A project of museum-mobiles will be implemented in order to make the collections of the National Museums and other museums available to people in locations where it is not possible to otherwise provide the special facilities necessary for presenting collections" (p. 6).

-additional funds for extension and education activities of the national museums.

-"the development of an inventory of major museum holdings in Canada" ( $p$. 7).

-"a program of catalogue assistance whereby museums throughout Canada will receive help to catalogue their collections..." (p. 8 ).

-"the establishment of a Canadian Conservation Institute with a complementary network of satellite laboratories" (p. 8).

-"the development of a detailed training program in the form either of periods of training at canadian or foreign museums, of a continuous training program at a school of museology, the details of which remain to be worked out" (p. 9). 
- "The establishment of a National Popularization Program [which] has yet to be concretized. We are however, establishing a research fund that will deal with this and other concerns. Its first task, as a groundwork for a diffusion program, is to undertake a scientific study of the museum public (and non-public)" (p. 9).

Many of these ideas and proposed programs eventually became part of the National Programs of the National Museums Corporation. This corporation, established at arm's length from the federal government, was thus given a major role in Pelletier's democratizing and decentralizing mission.

The excitement over this sudden infusion of funds was general, and there was some confusion. A committee member charged with recommending the disbursement of over $\$ 9$ million in one year details the situation:

... it must be remembered that when we got started, other than the Chairman and the secretary, the Consultative Committee Members really knew very little more about the program than did anyone who had read the Secretary of State's policy statement in the Gazette... (Broadland, 1972:12).

Pelletier had expressed the hope that the new allocation of funds would be increased, but it never was. In fact, it was soon decreased as the federal government faced changed economic circumstances in the mid-seventies.

Pelletier's policies were revolutionary in the Canadian context and in the patterns of federal museum policy. It was an aberration, in fact, to the previously prevailing pattern of seeing the federal museums as the prime instrument of federal policy, and major centres as the natural beneficiaries of cultural activities: 
It seems to me that cultural activities are no longer the exclusive preserve of Toronto and Montreal. Henceforth the creator's talent and the consumer's interest will find expression throughout the country (Pelletier, 1972:1).

In her paper, "The Evolution of Federal Support to Museums and Art Galleries", Anita Rush (1987) notes how the stage had been set in the 1960's for this reorientation of federal museum policy. Previously, cultural agencies had been dispersed throughout various ministries, but beginning in 1963, they were brought under the secretary of state. She suggests that this reorganization was related to the interest of the government of Lester Pearson (prime minister from 1963 to 1968 ) in promoting national unity through the efforts of cultural organizations. Particularly influential was the work of Gordon Sheppard, a consultant to the secretary of state. In a four volume review of federal cultural policy, sheppard recommended that

...the National Museums and National Gallery make grants available to non-federal organizations and individuals to pursue heritage-related activities, that a national conservation lab be established to serve Canadian museums (later to be replaced by regional facilities), that national inventories of museum and art gallery collections be created, and that the National Gallery and the National Museum cooperate with larger regional institutions in developing extension programs to serve institutions of all sizes (Rush, 1987:21).

Some of these ideas were not new and date back to the Miers-Markham and Massey-Levesque Reports. It is interesting to note that sheppard recommended against uniting the National Gallery and the National Museum, 
because, "personal tension and serious administrative wrangles will inevitably arise among them" (cited in Rush, 1987 , footnote 37 ).

Rush describes Pelletier's National Museum Policy as, "the first (and to date the only) coherent policy of support to non-federal museums and art galleries" ip. 24). She notes links with the 1968 Liberal election slogans of, "the just society" and "participatory democracy" and connections with contemporary French cultural policy. There were contradictions in Pelletier's approach. His interest in, "making the federal presence known throughout canada" (cited in Rush, 1987:28) smacks of cultural imperialisin rather than democratization and decentralization. Consultation with the provinces was not on his immediate agenda. Pelletier later stated that, "we never had... a federal-provincial conference because of the pretension of many provinces was that we had no role to play" (cited in Rush:32). In the end what seems to have developed was, paradoxically, a centralized attempt at decentralization:

Curiously, in Pelletier's efforts to democratize and decentralize access to museum collections, the National Museum Policy emerged as highly centralist. It created a single national computer-based inventory of collections and a single national museum-oriented conservation lab. It proposed to draw a number of autonomous institutions into one of two networks that would be sponsored by the federal government. The National Museum Policy did not provide for programs to be differentiated on regional or provincial levels; instead, it strived for national services for the entire Canadian museum community. The strong national 
thrust of the National Museum Policy could be defended on technical grounds, but it was an interesting approach from an inter-governmental standpoint, given heavy involvement of the provinces and territories as the major and increasingly more dominant source of support to the museum community (Rush, 1987:35-36).

The national association representing the interests of museums and museum workers, the Canadian Museums Association (CMA) (founded in 1947), published a brief in October of 1971, in response to Pelletier's speech during "Consultation I", a conference held in Ottawa. The, "Brief on the Eleven Points on Cultural Policy as it Applies to Museums, As Stated by the secretary of state," in general expresses support for Pelletier. The Association notes that there were problems of definitions, democratization and decentralization meaning many things to various people. It particularly objected to the use of the term, "affiliated museum," because of its centralist connotations, and suggested its replacement by the term "associate":

It is felt the interaction should be on a co-operating basis; associate museums retaining their autonomy. It is also possible the associate museums could participate in the supervision of the program (Gazette, 1971:8).

Pelletier accepted the change of term.

The Association also objected to an emphasis on the acquisition needs of the National Museums, stressing the need for cooperation among museums over competition and ensuing price escalation. It stated that the "national patrimony is by no means confined to the National Museums" (Gazette, 1971:8). There was consequently, the Association 
felt, the need to give preference to the establishment of a national computerized inventory in order to facilitate an assessment of collections' needs.

The CMA offered its assistance in the elaboration of training programs and in evaluating the capability of museums for becoming associates. The Association fully supported expanded centralized facilities for the National Museums :

If Canada is to be considered an entity... then it is wholly appropriate that the principal museums of a national character should be located in the National Capital. Certainly study and reference collections should not be disseminated, since their value is in direct proportion to their completeness and accessibility. The CMA/AMC recommends that the National Museums be given the space needed in ottawa to maintain and display collections which are really national in scope and character... (Gazette, 1971:8).

The Association seemed curiously wary of the proposed

National Popularization Program, feeling that the term suggested a reduction of standards:

there is a genuine fear in the minds of many museum professionals that in the hands of the media the museum will be used but not served; it is also believed that neither will the public, as in many cases the museum object is merely used as an adornment rather than an object for educational purposes. Perhaps this problem could be solved if the media would actually work with rather than exploit, museum professionals... (CMA, 1971:10).

In general one has the impression that during this period of time the federal Liberal government continued to set the agenda on museum policy. Consistent with its 1968 election slogans of "the just society" and "participatory democracy", attempts were made to increase access to 
cultural activities beyond the small elite that had previously viewed museums as their preserve. The staqe was being set, especially with the National Museums Corporation established as an arm's length agency and its major responsibility for federal museum programs, for the development of decentralized views that could compete with the official political views of the government of the day. Any government would consequently have greater difficultly in being dirigiste in its museum policy. This movement towards a greater democratization of museum policy came at a time of cultural change within Canadian society. The late 60 s and early 70 sitnessed campus revolts, civil rights marches, the growth of the women's movement, a general social turbulence and corresponding ideological shifts. The hegemonic structure of Canadian society appeared to be changing and the new museum policies of the Trudeau government can be viewed as an attempt to adjust. A reorganized hegemony appeared imminent. Chantal Mouffe, in her essay, "Hegemony and Ideology in Gramsci", has noted how cultural changes do not result in an elimination of the existing world-view, but a "rearticulation of existing ideological elements" (Mouffe in Bennett, et. al., 1981:230). The establishment of a new hegemony implies the transformation of the previous ideological terrain and the creation of a new world-view which will serve as a unifying principle for a new collective will (Bennett, et. al., 1981:229).

The Trudeau government was not abandoning the former 
use of national museums as national unifying symbols. In fact it seemed quite willing to override concerns of some provinces over the lack of consultation on its museum policy. What the federal government appeared to be doing was to extend those national symbols to subordinate groups through making the central government a major contemporary patron of the arts across the country. This government seemed to sense the need to extend, both geographically and socially, the range of hegemony.

The changed economic conditions of the mid-1970s, a reduction to minority status for the federal government, and a realization of the complexity and difficulty of implementing programs without the cooperation of the provinces, reduced the glow of the National Museum Policy. The funding of programs never grew; in fact, considering inflation, it actually shrank considerably. What remained intact was the administrative mechanism for accomplishing diminishing returns. Several attempts were made by the National Museums Corporation to revive and update the policy, but they never got off the ground.

\section{2: THE APPLEBAUM-HEBERT REPORT}

The impetus for a review of cultural policy came under the short-lived clark administration when, in 1979, Louis Applebaum was appointed chair of an advisory committee on cultural policy. With the return of the Liberals in 1980 , a 
co-chair, Jacques Hebert, was added and the committee became the, "Federal Cultural Policy Review Committee" (FCPRC). The Committee reported on all areas of federal involvement in cultural affairs. Its major recommendation affecting museums was the proposal to establish a Heritage Council:

15. The Government of Canada should establish an arm's length agency to be known as the Canadian Heritage Council, to be a visible champion of heritage interests in Canada, recognizing the importance and particular characteristics of those interests, to promote heritage arts and sciences and to support heritage institutions (Applebaum and Hebert, 1982:107).

According to this review, the National Museums Corporation was to limit itself to the supervision of the four nationals. Such bodies as the Museum Assistance Program, the National Inventory Program (later renamed the Canadian Heritage Information Network), and the Canadian Conservation Institute, all products of the National Museum Policy of a decade earlier, were to be administered by this new organization, a heritage equivalent to the Canada Council. The National Museum Policy is in fact blamed for causing, "the basic heritage activities of collection and conservation to be seriously neglected and minimally funded" (p. 119) because of the emphasis on democratization and decentralization. Although there are recommendations to make funding available to smaller institutions so that they may mount exhibitions and programs, the recommendation to establish an arm's length super bureaucracy is overwhelmingly centralist. A minority comment by committee 
member Guy Robert seriously questions expanding

administrative structures:

If we assume that we live in a rapidly evolving pluralist society, and if federal cultural policies ought to avoid imposing an of $\mathrm{f}$ icial culture, then these policies must aim at making federal institutions and prograns more flexible by adapting to rapid social, ideological, aesthetic and economic change. Too often our Report stresses the institutional role by recommending, for example, an increase in the budgets and duties of the Canada Council. In my opinion, this risks increasing bureaucracy, centralization and power mongering by officials... If we are to serve more effectively the cultural aspirations of the public in general and artists in particular, then $I$ feel that it would be preferable to reduce the number and size of large administrative structures, to increase the programs aimed at specific problems..., to listen to regional needs and to coordinate our activities with those by the provinces and municipalities (pp.364-365).

It is difficult to sort out this comment, although it is interesting to note that it comes from a Quebec member of the Committee. He expresses concerns over the imposition of an "official culture", but at the same time the delivery mechanism for museum programs was to be through the proposed Heritage Council at arm's length from the government. The main concerns seem to be over the danger of simply increasing the size of administrative bureaucracies whether or not they be at arm's length, and over the lack of cooperation with other levels of government. In Quebec, the spending power of the federal government in cultural affairs has frequently been a point of contestation.

The Canadian Museums Association came out in full support of a Canadian Heritage Council provided that it be primarily a funding agency and not the administrator of the 
Canadian Conservation Institute and the Canadian Heritage Information Network. The CMA recommended that this council be modeled after the Canada Council and be at arm's length from government. Also stressed was the need for additional resources for the Museum Assistance Program (MAP). Writing two years after the Review, the Association noted that the budgets of MAP had remained static and inflation had reduced the impact of this money:

Indeed, the priority is to establish a new base for federal funding of heritage. Simple percentage increments will not compensate for recent shortfalls nor, more importantly, will such increases; illustrate the new commitment to heritage on behalf of the federal government. A new base for funding will also allow for the introduction of realigned programs, and, significantly, for the establishment of the proposed Canadian Heritage Council (CMA, 1984:5).

For the first time the CMA seeks justification beyond the standard arguments of the educational, aesthetic and cultural values of museums, and alludes vaguely to tourism, described in terms of $a$, "leisure-time growth industry":

The cultural sector has been identified as a potential major growth sector for the $1980^{\prime} \mathrm{s}$. This potential for growth comes primarily from the fact that the cultural and heritage sectors are closely related to the educational sector and to the leisure-time growth industry. Given the increased "free" time now available to a very wide segment of the population, coupled with the greatly increased interest in adult education and self-learning, resources directed toward the support for the cultural sector will benefit not only the institutions themselves but more importantly, the visitors (CMA, 1984:5).

The vocabulary of political economy - resources, sectors, economic impacts - gains increasing use by the CMA and provincial associations in the mid to late 1980s. In 
part I of its response to the Report of the FCPR, the CMA had rejected the appellation, "cultural industry": "museums and heritage institutions are not a 'cultural industry'" (p. 18). This undefiled state is not long maintained. The Association also rejects government intervention in the arts marketplace. The Report of the FCPRC had recommended, "the creation of a non-government organization designed primarily to devise initiatives and provide impetus in the marketing and promotion of Canadian arts" (Applebaum and Hebert, 1982:345). The CMA affirmed its belief,

that there are private endeavours that are currently and actively undertaking this role; government involvement in the natural ecology of the marketplace is inappropriate (Canadian Museums Association, 1984:27).

Considering that the association represents not-for-profit organizations, such a stance seems peculiar.

The Report of the FCPRC marks a changed climate of state/non-government organization (NGO) interaction. It was possible with the National Museum Policy of 1972 for government to act in a unilateral way and leave an NGo such as the CMA struggling to keep above water. The editor of Gazette, the Associations's journal, in a note preceding the speech of Gerard Pelletier's announcement of the National Museum Policy, dolefully invites comments from the membership, "for there is no doubt that the CMA will be expected to respond to this ambitious program" (Pelletier, $1972: 3)$. It was in part the empowerment of NGO's through 
the funding made availatle by the National Museum Policy (over $80 \%$ of the CMA's budget in 1975), that enabled the CMA to more effectively respond to policy initiatives. At the time of the Massey-Levesque Report, the CMA had a budget of $\$ 300$ and no permanent staff. By the early 1980's there were at least 12 full-time staff members. By then the secretariat had the capability of producing its own briefs to governmert bodies. The CMA became a major advocate of federal support to non-federal museums. The means to achieving this, the CMA maintained, was through an expanded Museum Assistance Program.

The Trudeau government, still in power in 1984, had never developed a successful record of dealing cooperatively with the provinces. This government's tradition of unilateralism may have contributed to the lull following the Report of the FCPRC, for none of its policy proposals were acted upon. There could have been interesting implications for museums in Canada if an arm's length Heritage Council had been established. It was perhaps the wrong moment for the creation of such a body. This period marked a neoconservative shift in the political climate, which may possibly explain the increasing use of the vocabulary of political economy by the CMA and the introduction of the tourism connection. Conservative governments were in power in Britain and the United States. There was a serious recession in 1981 with interest rates hitting 21 per cent. 
The federal government deficit was also soaring. Economic arguments in favour of museums became essential before the government funding marketplace. The dominant business groups in Canadian society were increasingly looked to for providing a marketplace salvation for a broad range of problems.

With the change in government to Brian Mulroney's Conservatives, an intense period of policy review was set ir. motion, that included the production of such documents as the "Nielsen Review" (Nielsen, 1986), "Richard-Withrow Report" (Richard and withrow, et. al., 1986), the "Bovey Report" (Bovey et. al., 1986), and "Challenges and Choices" (Communications Canada, 1988). There was now a certain ceremony of policy making where extensive consultation, or at least the appearance of it, was an essential part of the unfolding social drama. The federal government had created this necessity through providing funds to such NGOs as the CMA. The challenge was now to "manage" the diversity of opinion. The sole exception to the consultation/ report/ response ceremony is the, "Study Team Report to the Task Force on Program Review" or, "Nielsen Review", named after deputy prime-minister Eric Nielsen. It is in this report where the real state agenda may lie, and it is to this report that we now turn. 
1985/86: THE NIELSEN REVIEW

The task force was created in september of 1984, just after the election of the new Conservative government, with, in its own words, the two main objectives of providing, "better service to the public and improved management of government programs" (Nielsen, 1986:i). The review was comprehensive, encompassing a wide range of government programs. Its orientation was, however, to identify areas of what is euphemistically termed, "spending restraint". The report pertaining to the Department of Communications was released in March of 1986. Any changes suggested were to be phased in over the time span of what remained of the 1980s. The review covered more than 100 programs involving an expenditure of $\$ 2,250$ million in such areas as natural and cultural heritage, performing arts, visual arts, broadcasting, film, video, writing and publishing. Recommendations relating to museums are overwhelmingly of a cost saving or revenue generating nature. To generate revenues for the national museums, admission fees, voluntary contributions and sponsorships are recommended.

Quite specifically, a target date of 1988 is set, one that would coincide with the expected opening of the new national museum buildings. The National Gallery did open in 1988, and a partially completed Canadian Museum of Civilization opened in 1989. Admission fees are now in 
force at all national museums and they are also recommended by the Review for special exhibitions. Such fees were implemented by the National Gallery for its first special exhibition on Degas. The recommendations for private sector sponsorship and friends-of-the-museum schemes have also been followed by both the National Gallery and the Canadian Museum of Civilization. The Nielsen Task Force also recommended the privatization of the administration of boutiques, restaurants and parking.

Among its other recommendations, the report suggests that all federal heritage institutions focus on the management of collections over new acquisitions, a proposal that would effectively exclude the development of collections relating to New Canadians. The de-accessioning of material not of national importance is observed to be an effective tool which could also result in the enrichment of local and regional collections. Major changes are recommended for the National Programs of the National Museums Corporation:

The objective to be pursued in this review could be to abandon the Museum Assistance Program entirely, on grounds that its impact has become too insignificant, and concentrate federal resources on the provision of services that are national by nature and would be uneconomical for individual provinces to set up... [CCI, CHIN, International Program]. This option could recover as much as $\$ 10$ million (p. 98).

The Mobile Exhibits Program is thought to have served its purpose and is recommended for termination, saving $\$ 3.2$ 
million. This was later accomplished. The report notes that the National Programs achieved spectacular results in the early 70s, but the situation has changed, the demand far exceeds available resources, procedures are complicated and expensive and the provinces now have grant programs. The savings to be realized from the termination of the Mobile Exhibits Program and the Museum Assistance Program were suggested to be directed to the fit-up of the new buildings:

The construction of these new buildings represents a considerable financial burden on the Canadian public... the study team suggests that existing resources be used to this end and priorities reordered if necessary to free up staff or funds. If the ten year period to bring exhibition space on 1 ine is adopted, as well as the option to terminate the Mobile Exhibits Program ( $\$ 3.2$ million) and reduce or abandon the grants program of the National Programs (up to $\$ 10 \mathrm{million),} \mathrm{it} \mathrm{should}$ be possible to meet most costs of fit-up and exhibition construction without new funding ( $p$. 100).

Alternatives to the National Museums Corporation were discussed. It was thought that a departmental branch of the Department of Communications could replace the corporation and continue to provide common services. However, it was thought that such a decision might be perceived, "as an attack on the 'arm's-length' principle" (p. 95) by the cultural community. Ironically, this same community in 1986 supported such a move in the form of the Richard-Withrow Report.

The Canadian Museums Association is funded in part by the Museum Assistance Program $(\$ 290,000$ in 1988 or in the 
range of $+40 \%$ of its budget). Provincial associations receive grants from MAP for their training needs. The Nielsen Review had very bad news for NGOs:

...the study team believes that service and advocacy organizations should be funded by members of the organizations so that they stay relevant to their constituencies (p. 207).

Significantly, the study team was not persuaded by economic justifications being forwarded as a rationale for the support of museums:

...the strictly economic justifications for public expenditures on arts and culture are positive but weak, particularly when compared to alternative economic programs. On the other hand the legitimacy of such allocations are strong on value-based terms ( $p$. 54). We thus see in the Nielsen Review an agenda in keeping with the political outlook of the new conservative administration. For the national museums suggestions are made regarding revenue generation through the charging of admission fees, the seeking of sponsorships and the privatization of the administration of restaurants and parking lots. The charging of admission fees could, however, result in restricted access to the nationais. Existing dominant groups in the corporate sector would stand to gain a greater symbolic presence and consequent prestige through the sponsorship of exhibitions. The Nielsen Review was proposing nothing other that the dismantling of the National Museum Policy of 1972. Such programs as the Museum Assistance Program and the Mobile Exhibits Programs, originally established in order to increase the access of 
all Canadians to their heritage, were proposed for elimination. These programs had in a sense become national symbols, MAP through, for example, the establishment of national standards in museum construction, and MEP through nationally travelling mobile exhibitions. The arm's length agency of the heritage field, the National Museums Corporation, was proposed to be replaced by a departmental branch. The savings that would be achieved were to be redirected to the fit-up of the new national museum buildings to alleviate tre need for new allocations of funds. The national museums would thus become the major beneficiaries of federal support to museums and non-federal museums would eventually be cut off from federal support. Such service and advocacy organizations as the CMA, empowered by the National Museum Policy to a fuller participation in the decision making process, would be enfeebled. That a number of recommendations of the task force have come into effect, and that the same government was returned in 1988 , could prove to be a significant presentiment for non-federal museums and NGOs.

\section{6: RICHARD-WITHROW REPORT}

In the same year of the report of the Nielsen Task Force (the Report was published in August of 1985, but not released until March of 1986), a series of seven task forces were appointed by Marcel Masse, Minister of Communications 
(responsibility for cultural affairs had been transferred from the Secretary of state to the Department of Communications), dramatically underlining the government's intention of conducting a thorough review of past practices and policies. The National Museums Task Force, co-chaired by former Quebec Minister of Cultural Affairs, clement Richard, and director of the Art Gallery of Ontario, william Withrow, was given five terms of reference in March of 1986:

Studying the operations and mandate of the National Museums of Canada Corporation, including its services to the Canadian museum community and its responsibilities for national collections and research;

Defining the role, or roles of the National Museums of Canada ;

Examining the National Museums Policy of 1972 and assessing the effectiveness of its application for the future ;

Recommending the means whereby the four National Museums... can best carry out their roles;

Reviewing the roles of small museums supported by the Government of Canada and making recommendations concerning their activities and relationship to the NMC (Government of Canada, 1986: Annex I).

The first recommendation of the Task Force was for the dismantling of the National Museums Corporation and to establish four autonomous national museums. The Museum Assistance Program was recommended to be replaced by an omnibus Museum Support Program that would be established through long-term agreements with the provinces. The Canadian Heritage Information Network was suggested for. termination ("devolved to the museums"), as was the Mobile 
Exhibits Program and the International Program. The Canadian Conservation Institute was to be substantially reduced in scale. (The Task Force very obligingly offered to do for the government its cost-saving dirty work.) The savings resulting from these terminations and reductions were to be allocated to the new Museum Support Program and other new programs:

In view of the limited financial resources available, the Task Force did not want the recommendations in its Report to incur significant new expenditures on the part of the federal government (Richard and withrow, et. al., 1986: 43).

The Nielsen Task Force need not have feared the cultural community's reaction to ending the arm's length status of the National Museums Corporation, for the community, through the Richard-withrow Task Force, did it for them:

that the new programmes of assistance fall under the direct responsibility of the Minister of Communications, that an Assistant Deputy Minister be specifically designated to administer these programs... (p. ix).

If the report of the Nielsen Task Force represents the state agenda, then the Richard-Withrow Task Force delivered part of it promptly and at no additional cost. Not all parties concurred on all matters, however. The Caradian Museums Association supported autonomy for the four National Museums, a better financed museum support program, long-term federal-provincial agreements, the termination of both the Mobile Exhibits Program and the International Program, but 
felt that any change in the status of the Canadian Heritage Information Network and the Canadian Conservation Institute needed further study. The Association also didn't accept the redirection of savings as the sole $m$ ins of expanding programs, but recommended an additional $>$ su million for the Museums Assistance Program. The Association was noncommittal on whether the arm's length National Museums Corporation should be ended or whether an on-line department of the government should be established to administer programs.

The CMA strongly rejected the Task Force suggestion that associations be supported by service contracts. To the Task Force reservations on the dependency created by operating grants, the CMA responded that it, "provides a unique and essential link between the federal government and the museum community," and urged, "the federal government to recognize the importance of this service by providing an endowment fund..." (CMA, 1986:3). The Association could hardly be expected to urge otherwise. Its ability to put forward the views of its membership was being seriously threatened by the Nielsen and Richard-Withrow task forces, especially when members of the latter task force were also members of the CMA. With over 40 per cent of its budget emanating from the federal government, its stability would be seriously undermined by a withdrawal of support.

The government responded to the National Museums Task 
Force by agreeing to dismantle the National Museums Corporation and establish four autonomous federal museums, undertaking the formulation of a new museum policy in consultation with the museum community and provincial and territorial governments, and agreeing that the Mobile Exhibits Program should be terminated. The government agreed with the standing Committee on Communications and Culture (an all-party House of Commons committee) in retaining $\mathrm{CHIN}$ and $\mathrm{CCI}$, but when it came to increasing funding for museum support programs, agreed only to redirect savings from the termination of some programs. The standing Committee recommended that an arm's length agency administer the museum support program and not a federal government department. The government disagreed, stating its intention to transfer these programs to the Department of Communications. (The chairman of the Board of the National Museums Corporation, Gerard Pelletier, had previously resigned. During a speech at the annual conference of the Canadian Museums Association in Winnipeg in May of that same year, Pelletier criticized the attitude of some members of the museum community who seemed to hosd the fallacious hope that more funds to museums would flow if there was a direct link with government.) The federal government with the apparent support of the museum community through the Richard-Withrow Report, thus ended its arm's length agency that supported both federal museums and programs for non- 
federal museums across Canada and ended the Mobile Exhibits program. These bodies had originally been established in order to increase the access of all Canadians to their heritage, and accomplished this at an administrative distance from their source of funds. Federal museum policies appeared to be moving in a more restricted and dirigiste direction.

\section{6: THE BOVEY REPORT}

Another of the task forces set into motion by Marcel Masse was the Task Force on Funding of the Arts. The result of its inquiry, commonly referred to as the, "Bovey Report," after its chairperson Edmund Bovey, was also published in 1986. The task force had been mandated, "to inquire into the means by which the arts in Canada can be more effectively funded" (Bovey, 1986:19). In general, government, the private sector, "consumers," and the arts community are enjoined, as funding partners, to "pool their resources". A growth rate of $5 \%$ per year (constant dollars), or $1.5 \%$ over economic growth is recommended as an objective for arts funding to the year 2000. Both the federal and provincial governments are recommended to increase their funding by $4 \%$ per year, while the rate of increase for municipalities is recommended to be $7 \%$. The suggested rate of growth for business support is $9 \%$. These recommendations for increases in support immediately 
confront at the federal and provincial level, concern over deficits. Municipalities face more immediately than other levels of government, the ire of taxpaying citizens over rate increases. There are also difficulties in developing high expectations of corporations. According to a study by Decima Research, corporate donations to charitable organizations have dropped by $32 \%$ since 1969 (Museogramme, February, 1988:7).

There are sixty recommendations in the, "Bovey Report". A minority of these directly implicate museums. Museums and art galleries are, for example, recommended to charqe admission fees (or request voluntary donations) while, at the same time, setting aside periods for free admission. Membership fees should result in net funding benefits to these institutions.

The Canadian Museums Association, in its brief to the task force, reaffirmed public support, "as the basis on which Canadian culture is built and will continue to grow" (CMA, 1985:1). Although all levels of government are viewed as participants, federal financial support is particularly addressed. Federal support is considered to be appropriately directed through the proposed Canadian Heritage Council (a recommendation of the Applebaum-Hebert Report rejected by the federal government in favour of establishing a direct government department). The Association feels that the priority should be placed on 
increasing attendance over increasing admission fees. A vision of the economic impacts of increased tourism is raised:

Increased attendance would have more overall economic impact especially upon the tourism industry which heavily benefits from neighbouring museums, historic sites, and nature parks. In terms of the U.S. market which the government is interested in attracting, a recent study prepared for the Minister of Tourism indicates that Americans find our cultural differences to be the primary motivating factor in deciding to visit Canada. Museums, historic sites and other cultural activities are in a prime position to attract large numbers of tourists. In a sense, we are the marketing "loss leaders" by providing low cost and universal accessibility (CMA, 1985:25).

The Association also believed that the revenue

generating potential of museum shops is underemphasized, and proposed a Canadian Museum Shop Marketing Agency. A funding policy is also recommended for national associations. The one recommendation eventually acted upon was one concerning a labour market study of the museum field. The study was funded by the Lepartment of Communications (Ekos, 1988).

\section{8: CHALLENGES AND CHOICES}

with the release of, "Challenges and choices: Fedt ral policy and program proposals for Canadian museums," in May of 1988, we see the full acting out of the ceremonial process of policy development: a policy paper is released by government for consultation and feedback, a policy team travels across Canada in this exercise, submissions are invited, the policy team goes to work apparently on these 
submissions, a new museum policy is brought forward and then an opinion management process begins. In her introduction to "Challenges and Choices", then Minister of Communications Flora MacDonald, sets the mood:

This discussion paper comes at an opportune moment in the development of all museums in Canada. Despite the current reality of financial restraints, museums must prepare for the challenges of the future... This paper is intended to stimulate a dialogue among Canadians about our museums. This dialogue will assist the Government in revising its policies and programs to help Canadian museums... I believe that a new federal museum policy must be a co-operative venture... (Communications Canada, 1988:5-6).

Although Canadians are invited to participate in the policy making process, they are viewed in a passive sense as, "cultural consumers" (p.60), with an ever increasing amount of leisure time to devote to consuming. It is rarely noted that not all Canadians have this accumulating leisure time and that the phenomenon is restricted. "Challenges and Choices" is more specifically addressed to the, "museum community," which it defines as

all those who interact with museums: all levels of government, the education and business sectors, freelance curators and exhibit fabricators, volunteer and support groups, museum trustees, researchers and scientists, private collectors and donors (p. 29). The increasing use of the language of political economy has been noted. The phrase, "museum community", comes across as rather friendly, although certainly exclusivist. The concept of "cultural consumer" to designate the visiting public is in the ascendancy in the 1980s. Jody Berland, in her study of the Applebaum-Hebert Report, notes how this 
concept has surreptitiously replaced the more affirmative concept of the "citizen" (Berland, 1985:56). In this scheme of things, then, museums produce cultural products for a consuming public. The proselytizers of this ethos carry with them all of the allure of hard-nosed economic common sense.

The policy proposals of "Challenges and Choices" (a relatively small section of the document), are as remarkable for what they don't say as what they do say. The document is also interesting in its progression by statements and questions. After stating four broad policy objectives, the reader is asked: "Do you agree with the proposed policy statement and objectives? If not, what changes would you propose? Why?" (p. 69). The approach is certainly conciliatory. The policy statement itself is a type of mother/fatherhood formulation that is fairly difficult to disagree with:

The federal policy for museums is: to foster public awareness, understanding and enjoyment of Canada's human and natural heritage through the collection, preservation, research, presentation and interpretation of significant and representative collections of that heritage ( $p .67$ ).

Proposed policy objectives seek to promote access, awareness and understanding, representations of diversity, and, the favourite and most meaningless phrase of the $1980 \mathrm{~s}$, excellence. One can seriously wonder, however, whether the agenda hasn't already been set. As noted, there is a surprising correspondence between the lower profile Nielsen 
Review and government action. There is also a need to be equally alert to what is not discussed. Highlights of the "Challenges and Choices" follow.

The federal government retreats from the massive intervention practices of the 1972 National Museum Policy:

The size and diversity of this country dictate that many activities are best handled at a local or provincial level, by the people most closely attuned to the situation ( $p .70)$.

A return to the pre-National Museum Policy orientations is advocated:

The national museums are the federal government's principal instruments for achieving its museum-policy objectives (p.70);

The national museums will undertake research and programming activities to reach Canadians across the country. In doing so, they will be expected to work co-operatively with the larger canadian museum community in order to further common objectives $(p .71)$.

International cultural relations are seen to be the domain of the federal government:

While it is normal for major museums and provincial governments to undertake or support activities on an international level, state-to-state negotiations are the prerogative of the Government of Canada ( $p .71$ ).

with regard to the provision of national services, it is felt that certain of them are best provided at a national level. These are thought to be: the facilitation of the communication and sharing of information and advice, the Canadian Conservation Institute ( $\mathrm{CCI}$ ), and the Canadian Heritage Information Network (CHIN). significantly, there is no discussion at this point of 
the support programs to non-federal museums. Financial support is discussed in terms of meeting federal priorities:

The federal government has contributed financially to the growth and development of Canadian museums. While the need for financial assistance continues, the Government proposes to re-orient its support to areas that will be identified as priorities as a result of this consultation process ( $p .73)$.

The proposed federal priorities are: collections development and maintenance, enhanced public awareness, access and understanding, and management development. In the elaboration of these priorities, the present range of federal services to museums is discussed, but with a clear warning:

Allowance must be made for budgetary constraints. While a range of federal activities is suggested in the following pages, it is clearly not feasible to accomplish all things in all areas. Funding limitations dictate that choices must be made. Increased spending in one area may imply reductions in other areas ( $p .77)$.

One of the more innovative suggestions is for a national museum awareness campaign modelled after the promotion of physical fitness through the PARTICIPACTION program. It is suggested that the CCI, the national museums and the Movable Cultural Property Program make greater use of the media in promoting awareness in their domains.

The role of associations is seriously questioned by Challenges and choices. The following ominous questions are posed:

What role could or should the various museum associations play in terms of program delivery and overall museum development? What federal funds, if 
any, should be provided to them for these purposes? Should associations broaden their financial base in order to be less dependent on government funding?

(p. 93).

Understandably, the Canadian Museums Association felt

quite threatened by "Challenges and Choices", and responded by asserting that the federal government, "has a valid role in funding these organizations, national, regional and provincial," (CMA, 1988:13) and recommends that a new funding base be established for the CMA. The tone is justificatory:

the Canadian Museums Association is widely recognized for its role both by the museum community, and as a model by many other professional cultural organizations... It... acts as an advocate on museumrelated issues which activity is clearly funded from membership and other revenue other than government support. The government benefits from the CMA as a source of advice and information for formulating policies and programs, as an agency to administer many important programs and to communicate federal initiatives to the community ( $p$. 13).

The CMA's brief continues by complaining of the financial strictures of the Association, before recommending that the CMA and other associations, "become the efficient deliverers of some of the exciting program suggestions..." (p. 14). The Association recommends itself for delivery of the Museum Advisory Service (a new program that is not well defined) and an expanded Bursary Program (a program funded by the government but presently administered by the CMA). Substantial new funds are recommended for a new Museum Assistance Program ( $\$ 43$ million) where, of course, the Association would in part be the beneficiary. 
The CMA was willing to talk challenges, but wouldn't talk choices. It was seeking a renewed and revised position in the hegemonic order. The question of survival had forced it to abandon its position in response to the RichardWithrow Report, that it should not be supported by service contracts. Should the national museums, as recommended by Challenges and Choices, become the principal instruments for the government to achieve its museum-policy objectives, then the advocacy role of the CMA would become redundant. There would no longer be any non-federal beneficiaries of federal support to advocate for.

The Association's brief categorically rejects the proposal that the national museums become the principal instruments for the government to achieve its museum policy objectives:

These museums are the responsibility of the government of Canada, but it is unthinkable for the federal government to concentrate all of its activities solely on the federal museums, and to neglect the other public collections which comprise the national heritage (p. 11).

The attempt at realigning and redesigning a federal role ominously sıgnified by the title, "Challenges and Choices," is rejected by the CMA. The Association recommends a fairly orthodox expansion of that part of the National Museum Policy that concerns non-federal museums. Titles seem to be significant here, and the CMA chose to entitle its brief, "Expansion and Innovation". The brief is, however, a little short on innovation, but tall on 
expansion.

Some previous recommendations are revisited by the CMA. The Heritage Council of the Applebaum-Hebert Report and the creation of a deputy ministry responsible for museums, are two options described as having support. The former is arm's length, while the latter isn't. The CMA was not a strident defender of the principle of an arm's lenqth aqency administering museum support programs auring the deliberations over the Richard-Withrow Report. Gerard Pelletier's warning over the naivete of the expectation of more money through departmental connections has been referred to. Pelletier also criticized the abandonment of the arm's length principle at a later date in, "La Presse":

La Corporation disparue [National Museums Corporation]. tout obstacle à l'imposition des vues ministerielles, voire partisanes disparait du même coup. Toutes les conditions sont donc realisees pour que s'exerce librement un dirigisme culturel auquel. tous les gouvernements canadiens s'étaient toujours refusés (June 8, 1988).

Another cornerstone of the National Museum Policy seems to have been reassessed by the Association, that of decentralization:

Cultural expression and articulation must begin at home. It cannot and should not be imposed from the centre. It must flourish in the small communities and in the regions before it becomes enshrined at the centre. Just as our country can only be as strong as its regions, our national museums in ottawa, and elsewhere, can only be as strong as the sum of the total community. Decentralization is no longer appropriate; rather the federal government must be a facilitator for the regions to express themselves nationally (CMA, 1988:3). 
Surely this conception of decentralization is contradictory. The brief seems to be speaking of issues of decentralization and empowerment, and then comes to an illogical conclusion. Whatever was the intent here, the brief later proposes the possibility of decentralizing the national museums:

we do not feel it is a given that all museums must be located in the National Capital Region. Consideration should be given to placing some of the needed federal institutions or branches in various regions ( $p$. 11).

This represents a change in belief from the point of view expressed in the CMA's brief on the National Museum Policy of 1972 .

In summary, the CMA response to Challenges and Choices is not as much a path to a new cultural policy for museums as it is an arqument for additional funds to continue with much of the same. The Association seeks to secure its place in ary new order and justifies that on the basis of its record. Justification for the additional federal investment in the proposed expansion is found in arguments concerning cultural values, job creation and tourism:

Such an investment, it must be recognized, will not only permit the museums to better meet their needs, but more importantly will benefit hundreds of thousands of Canadians. Tangible benefits have been identified in other studies and reports. Citizens will have greater access to their heritage, from all regions. Tourism will be enhanced. Public education will be furthered. Job creation wiil be accelerated ( $p$. 5).

The tourism link is thought to be a particularly strong card. In an address to the Tourism Outlook Conference in 
December of 1987 , sponsored by the Department of

Communications, the executive director of the CMA referred

to museums as the tourism industry's "loss leader", because

of the minimal costs to tourists for using museums:

museums are one of the greatest resources for the growth of the tourism industry in this country. I firmly believe we could dramatically increase the scope of tourism to, and within, Canada, with a strong working partnership... We need you to help lobby governments, at all levels, as well as the private sector, for improvements to museums... What we need is more operating support not just for promoting but research, conservation to improve the existing facilities, to provide more exciting programs, and to establish marketing and development staffs in our museums (McAvity, 1987:14).

The argument presented is that museums attract a

very up-scale visitor. Museum visitors in both the U.S. and Canada are likely to be in the upper education, occupation and income groups... This, of course, is one of the most sought after markets in the world. (p. 1-2).

Some sort of partnership seems to have concretized, at least between associations. In a February, 1989, press release by the Tourism Industry Association of Canada (TIAC), the federal government is urged to implement a new museum policy with new programs and increased funding:

Museums are one of the prime attractions for tourism development in Canada... We are convinced that museum attendance will grow even more [from the 92 million cited] with improved facilities, more exhibitions and better marketing... Improved museums will not only better preserve our heritage, they will also be excellent investments in the tourism industry (Tourism Industry Association of Canada, 1989).

The above statement was made by William Rowe, chairman of TIAC. In the same press release, John McAvity, executive 
director of the CMA is quoted as responding:

We are delighted to receive such a strong endorsement from the tourism industry. This is an excellent example of business and the cultural community working together.

The same press release notes, incorrectly, that, "funding for museums is through the Museums Assistance Program... The funding level has not changed, even for inflation, since 1972". The diversity of funding sources for the average museum is not at all alluded to. [The similarity of text is not a coincidence. Press releases are staged events where the appropriate quotations are supplied. Association links exist (for example, the Institute of Association Executives) that facilitate such staging.] For museums, the tourism argument seems to be the argument of the day.

"Challenges and Choices" articulates a Conservative government's concern for spending restraint within its museum programs as a means to alleviating its budget deficit problems. The government proposes a return to elements of the pre-National Museum Policy situation as a route to achieving this. For example it is proposed that the national museums are to become the "instruments" for achieving its museum policy, that provinces and municipalities assume a greater responsibility and that associations "broaden their financial base" in order to relieve the federal government of the burden of support. In addition, an arm's length agency, the National Museums 
Corporation, was eliminated, placing proqrams for nonfederal museums within direct departmental control and increasing the likelihood of a dirigiste museum policy, a move that also seems philosophically attuned to the Conservative government. With regard to additional and/or ongoing support for non-federal museums there is a discreet lack of detail. "Challenges and Choices" thus seems consistent with many of the recommendations of the "Nielsen Review". The repercussions for Canadian museums have already been discussed in terms of a restricted geographic and social access to museums. Such a move would appear to facilitate a return of museums to a more exclusive use by dominant social groups as a privileged symbolling domain (although the role of the provinces in providing support must be considered here as well). The Canadian Museums Association seems to in part support this development through its use of the tourism argument and how museums attract the "up-scale visitor" with higher education, occupation and income. Ironically however, a move away from federal support for non-federal museums through the Museums Assistance Program and from such programs as the Mobile Exhibits Program, deprives the central government of significant national symbols of unity and presence. 
CONCLUSIONS

Federal cultural policy regarding museums in Canada has at times been nonexistent or ad-hoc and at other moments carefully articulated and possibly in advance of the will of the museums themselves. The Miers-Markham Report, although not a policy, documented the lack of one and the state of museums in the 1930's. The worth of museums was viewed as residing in their educational value:

If the museums and art galleries are to be regarded, equally with the libraries, as a necessary part of the educational equipment of every considerable town, it is quite clear that a great deal has to be done before this idfal can be realized (Miers and Markham, $1932: 48$ ).

The Massey-Levesque Report continued to chronicle the woeful state of museums and an apathetic public:

It is probably true that most Canadian citizens remain throughout their lives quite unaware of the pleasure and enlightenment which an adequately planned and equipped museum could give them. The sorry plight of museums in Canada is appropriately matched by a widespread public indifference to their inadequacy (Massey et. al., 1951:92).

This chronicle derived from an elite perspective of culture:

Culture is that part of education which enriches the mind and refines the taste. It is the development of the intelligence through the arts, letters and sciences (Massey et. al., 1951:7).

The Commission thought that national cultural institutions could be a means to promoting national unity. They form, following Gramsci's analysis, the cultural "cement" that could hold the country ideologically together 
for a dominant class.

The National Museum Policy of 1972 established the first federal museum policy for Canada from a populist perspective with ideals of democratization and decentralization. The funding made available empowered such groups as the Canadian Museums Association to be fuller participants in the policy making process. The Liberal government of the day, in response to a changing political situation, appeared to be "educating" a broader social and geographic consent.

The Nielsen Review of 1985 can be seen as an attempt to reassert federal government control of expenditures and bureaucratic structures. With the suggested elimination of the arm's length National Museums Corporation and its replacement by a department, the government could establish a more dirigiste museum policy that would consequently be more responsive to its political agenda. With the RichardWithrow Report the federal government vicariously achieved some of its objectives in eliminating an arm's length organization and bringing museum programs under a departmental wing, without, most importantly, the expenditure of additional funds. "Challenges and choices" represents an attempt by the federal government to restore the pre-1972 situation as far as once again making the national museums the instruments of achieving federal policy objectives. With the costs of building and equipping the 
new national museums, the federal government fairly clearly does not wish to simultaneously expand existing programs of financial support to non-federal museums and non-government organizations. The risks of restricting access to museums does not appear to be of great concern. This is a dramatic departure from the eqalitarian concerns of a previous decade for involving groups from a greater cross-section of society. Gerard Pelletier's disquiet that public funds not be used for cultural activities, "reserved for the happy few", seems to have been swept aside.

changes in federal policy towards museums have thus occurred within a context of changing perspectives of the utility of museums. The most recent rationale has involved museums and museum associations in the tourism debate. The briefs of the Canadian Museums Association exemplify this. The CMA, representing primarily non-federal museums, but also through membership, federal museums and museum workers, has seen its position erode and can see further erosion through "Challenges and choices". Perhaps partly in desperation, and partly to be on the crest of a wave, it has turned to the tourism panacea as justification.

In June of 1990, Marcel Masse, federal Minister of Communications, announced a new, "Canadian Museum Policy" (Department of Communications, 1990) during a speech to the annual conference of the Canadian Museums Association in Edmonton, Alberta. The sixty page policy document was 
accompanied by a promise of an additional $\$ 53$ million over the next five years. Savings made by the ending of some programs (Mobile Exhibits Program, Associate Museums Program) and the straightlining of others (National Exhibition Centres, parts of the Training Assistance Program) are responsible for part of this increase.

It is still unclear what the full significance of the new policy will be, but $\in a r l y$ indications reveal an emphasis on the upscale. For example, the Training Assistance Program is to focus on mid-career and advanced level training at the expense of basic training. For provincial associations this means that their museum training budgets for 1990-91 are to be kept at the same level as the previous year. Provincial associations provide seminars of the greatest relevance to the larger proportion of community museum workers.

In a critique of the policy announcement, Jan Schroer, executive director of the Ontario Museum Association, noted that

it may be useful for the DOC [Department of Communications] to assess how programs affect the least among our sector. While federalism stresses national interests, a portion should be allocated for local needs (Schroer, 1990:8-9).

Schroer also questioned whether there had been federal consultation with provincial counterparts to ensure that provincial support filled the gap as federal support departed from basic training. Similarly, increases in 
support for exhibitions are aimed for, "international, interprovincial and provincial travelling exhibitions (Masse, 1990:5), and not for community museums. There is thus some evidence that the federal government is maintaining the rhetoric of democratization while placing funds in support of institutions and individuals already more powerfully endowed. Masse defines, "The search for excellence", as "being the ultimate objective of government support in the museum sector..." (Department of Communications, 1990:42). To announce a 1990 federal policy with the most hackneyed phrase of the 1980's -- "the search for excellence" -- may prove ominous for the democratization of Canadian museums.

In Chapter 3 which follows, the National Gallery as a hegemonic apparatus of the state will be discussed in terms of its orthodox role as provider of cultural continuities. Federal policy, however, allows the Gallery to operate at arm's length from the government and also to engage in potentially counter-hegemonic activities. This contradictory role and how it allows the Gallery to be the locus for the generation of new culture, will be discussed in Chapter 4. 
CHAPTER 3

THE ROLE AND INFLUENCE OF DOCENTS IN THE NATIONAL GALLERY

OF CANADA

The case study which follows on the role and influence of docents, or volunteers, at the National Gallery of Canada, allows a consideration of this institution as an apparatus of hegemony, one which maintains and reproduces culturally orthodox and elitist views about art, culture and the role of art museums in society. Art museum volunteers, it will be argued, function as quardian angels of a theoretically public institution and promulgate an ideology of art that is supportive of their privileged position in Canadian society. That ideology, which views art as a transcendental experience, is part of the prestige of a dominant class and is also part of the "cement" necessary for maintaining their hegemonic relations. Parallels will be drawn between the world-view of volunteers and federal policies which extend back to the Massey-Levesque Report. The latter saw the arts as a means to enlightenment, refinement and delectation. Policy, it will be arqued, has not been necessary in support of the presence of docents at the National Gallery. Their presence has been part of an ongoing force of social conservatism. Policy, in fact, has been introduced to weaken the influence if such forces in order to democratize museums. According to Statistics Canada's $1984 / 85$ Survey of 
Heritaqe Institutions, $43 \%$ of museum staff are volunteers. This large proportion of volunteer support can't be equalled in other sectors of the labour force. (Leisure activity24.1\%, religious- $25.5 \%$, health- $7.9 \%$, education- $16.3 \%$, social welfare- $31.5 \%$, civic community action- $3.2 \%$, political organization- 4.48 , other-9.1\%) within art museums, those volunteers involved in education programs are called docents. The word, "docent", is derived from the Latin, docere, meaning to teach, instruct, or inform. At the National Gallery of Canada, approximately $50 \%$ of its education workforce are volunteers. Along with security quards, they are the representatives of the museum with whom the visiting public is most likely to interact.

The level of this volunteer support can mean a number of things. It could simply be interpreted as a demonstration by volunteers of belief in the life and work of museums, in their significance, utility and benefit to society. On the other hand, it can be argued that volunteerism is a device for creating a world view for the museum. This chapter proposes to advance the latter interpretation. There already exist sufficient accounts of the selfless devotion and enthusiasm of the museum volunteer. Within a class contained analysis, this is undoubtedly valid. But once the elite character of art museum visitation is considered, and this is contrasted with the not for profit publicly funded nature of such museums, 
the question of fairness arises. As Gerard Pelletier remarked in announcing the National Museums Policy: "...it would be unfair to promote cultural activities that are reserved for the happy few" (Pelletier, 1972:4).

In spite of attempts at the democratization of museums, which Robert Kelly, an anthropologist at the University of British Columbia, suggests is primarily out of fear of losing public financial support (Kelly, 1985:21), a 1974 survey showed that only $20 \%$ of the Canadian public visited an art gallery. These visitors were typically well educated (648 had a university degree), ard with above average incomes (Dixon, 1974).

The phenomenon of volunteers is considered here simultaneously with the notions of altruism and philanthropy. The philanthropic benefactor, ordinarily deriving income through capitalist business, has the economic means to indulge in 'benevolence'. This love towards humankind cannot be taken at face value. It is directed and contains proprietary elements that, in the case of museums, can be seen to serve class specific ends.

Art museum volunteers may not be of the great means of the philanthropist. They are, nevertheless, not without their motivations. It is to the unveiling of motivation and its consequences within the social structure that this study will eventually turn. It is a preliminary study that attempts to outline major themes, but one that would benefit 
by the empiricism of fieldwork. Nevertheless, from existing literature on art museum education, an attempt will be made to firstly, socially locate museum volunteers. Their work in art museums will be described, with speciftc teference to the National Gallery of Canada. Such work implies a knowledge of art. This knowledge is in part gained through the class specific socialization of the volunteers, and through the training provided by the paid staff of education programs. (I am aware that any official text produced by art museum staff may be contradicted by docents, but this is not the focus of this thesis;. This training can also be socially located. The nature of this knowledge needs to be investigated in order to determine, in broad terms, its ideological content, and in order to determine not only who is the producer of this knowledge, but also in whose interest this knowledge is being produced. This whole process may be found, in the end, to reproduce the dominant ideology and to reinforce an elite control, not only of the institution itself, but of the whole society. Bennett has explained Gramsci's belief in the connection between culture and politics:

...for Gramsci there is a crucial link between culture and politics but the link is far from being a simple or mechanical one. Culture has to be broken down into its diverse forms, whether they be 'high' or 'low' culture, elite culture or popular culture, philosophy or 'common sense', and analysed in terms of their effectivity in 'cementing' complex forms of leadership (Bennett, $1981: 192)$. 


\section{A BRIEF HISTORY OF THE ART MUSEUM DOCENT}

Benjamin Ives Gilman, Secretary of the Museum of Fine Arts in Boston from 1893 to 1925, is credited with having introduced both the concept and term "docent" to art museums. In 1907, docent became the official term for the position of museum guide and teacher at this institution. In 1918, Gilman wrote a book "Museum Ideals of Purpose and Method" wherein he described both the philosophy and practice of museum work. The book was written not long after the completion of the new building for the Boston Museum of Fine Arts, and it is, in many ways, a 1918 state of the art publication. We are informed of, to take a selection from the table of contents, the nature and place of $f$ ine art, popular education in fine art, the aims of museums, the ideal of culture, the ideals of diagonal lighting and radial expansion, the ideal of composite boards, and the ideals of official companionship.

In inimitable period prose, Gilman describes the gardant (preserving), monstrant (exhibiting) and docent anctions of the museum. He resurrects these terms from 17th century English, and in the case of "docent", from the ritings of Archbishop Laud:

The church here is taken for the church as it is docent and regent; as it teaches and governs (Gilman, $1981: 279$ ).

A comtemporary of Gilman made fun of his coining of the word in the following limerick: 
The decent docent doesn't doze:

He teaches standing on his toes.

His student doesn't doze - and does,

and that's what teaching is and was

(Collins, 1981:298).

By the use of the word 'docent' Gilman wanted to avoid

any connotations of education. He contrasts the educational

work of schools with that of museums:

The school stands by its nature for relative excellence... The museum of art stands, on the contrary, for absolute excellence. It seeks to preserve only the best of the past. As docent, its duty is to aid its visitors, by the use of whatever means prove most effective, to assimilate certain of the highest achievements of minds at once mature and especially gifted (Gilman, 1918:83).

Only adults are to receive the benefit of this absolute excellence. He quotes George Goode, assistant secretary of the Smithsonian and a leading museum professional of his day (he had died in 1896):

I should not organize the museum primarily for the use of the people in their larval or schoolgoing stage of existence... School days last, at the most, only from five to fifteen years, and they end with the majority of mankind before their minds have reached the stage of growth most favourable for the reception and asssimilation of the best and most useful thought (p. 285).

In 1907, one of the assistants at the Boston Museum was given the title of "docent" and the duty of receiving visitors and giving information about the exhibits. By 1918, this function had grown to occupy several staff members. However, it was Gilman's feeling that docents should not be full-time professionals: 


\begin{abstract}
A docent is a companion among works of art, but he [note gender] is also not a companion by profession... That those invited to this duty should be otherwise employed during much the greater part of their time is its cardinal feature ( $p .315$ ).
\end{abstract}

The first volunteers had actually bequn their work at the Boston Museum in 1896. They were members of a voluntary association, the Twentieth century club, and were to give information to visitors on the cast reproductions in the galleries. Their work was discontinued when energies were devoted to the planning and construction of the new building.

Gilman documents similar efforts elsewhere, at the Louvre in 1901, in Germany in 1903, at two museums ir, New York by 1910, and in 1911 at the British Museum. Writing in 1918, he states that

the new word 'docent' has since become widely accepted among us in the new sense of an official commentator on things shown. A docent is one who explains exhibits. From the beginning this term has signified not an official post but an official duty; not a functionary but a function ( $p$. 308).

By the 1920s then, a tradition of docentry had been established within art museums who collected according to Gilman, "only the best of the past" within an institution that stood for "absolute excellence". A docent's duty was to assist visitors "to assimilate certain of the highest achievements of minds at once mature and especially gifted" (p. 283). 
THE DEVELOPMENT OF DOCENTRY IN CANADA

In Canada, the involvement of docents in museums

followed shortly after American and European experiments.

At the Royal Ontario Museum in Toronto, the first

opportunity to appoint a quide to the collections was

refused by the directors. A woman who had proposed herself

as guide was told that there was no such position. She

proceeded to conduct tours anyway:

It was then argued that she might be authorized to organize outside parties and lecture to them for a small fee, on the understanding that she was not on the staff... (Dickson, 1986:48).

By 1919, this volunteer had been hired by the Board and Toronto newspapers carried the story as, "Woman Guide for the Museum". This woman had to battle her way into the museum and certainly occupied a low status vis a vis other museum employees. The place of the docent in the museum heirarchy seems always to have been at the bottom, one Anerican museum educator commenting that they w'ere treated like, "museum lepers" (quoted in Newsome and Silver, 1978:242). The story of the Royal Ontario Museum docent also raises another aspect of docent work. It is not always volunteer, and there is at times some blurring of categories as volunteers are hired by museums. The question of gender is also raised by the involvement of volunteers at the Boston Museum of Fine Arts and the Royal ontario Museum. Gilman makes use of "he" as if any other pronoun was inconceivable. More recent literature almost invariably 
uses the pronoun "she".

Despite Gilman's earlier assertion that docent volunteerism was spreading in Europe, a 1976 survey of 52 North American and 21 European art museums found that docents were generally not a part of European art museun education programs. There seems to exist a quite separate tradition in Europe, involving questions of professional ethics and standards. The Head of Exhibitions and Education at the National Gallery (London) expressed the following opinion:

The human contribution is as important as any element in education, and if woney is provided to run an education department then all staff should be paid (cited in Hoskins, 1979:99).

The same question was raised in 1989 during my interview with Michel Cheff, tren Coordinator of Education at the National Gallery (Ottawa). He wondered if the level of art museum education wasn't being diluted by involving volunteers, and why volunteers should be involved in this area and not in curatorship (Grant, 1989: per $=n \pi a i$ interview).

THE CONCEPTION OF ART AND ITS UTILITY AS A STATUS MARKER It is my intention to ignore the work of docents in museums other than art museums, although such comparisons can be illuminating. In many ways, the involvement of volunteers at the Canadian Museum of Civilization (they are not called docents) is less elite driven. The CMC is not 
dealing for the most part with objects whose aesthetic element has been extracted for a transcendental function.

In the same interview with the Coodinator of Education Services at the National Gallery, the importance of attracting docents who come for the right reasons was stressed. During the docent interviewing process, those who are coming with the expectations of getting an eventual job are discouraged. The right personal motivations, according to Michel Cheff, involve providing something that is, "gratuit, altruist," and being in possession of, "a passion for works of art". Docents rieed to communicate their knowledge and passion. Just being part of an art museum is gratifying, just "being with beautiful objects".

This is quite indicative of the conception of art held by education staff. The view that art history is the history of artists, that the artist is a divinely inspired creator, is the one favoured by university art departments and art museums. The metaphysical notion of art is of too great a utility to drop in favour of one relating art to social context. Work of Marxist sociologists since 1945 , has extensively redefined the idea of art in society. This has not disturbed, for the most part, the conception of art held by art museums, and by those who work in them. Janet Wolff provides us with a very succinct description of recent Marxist analysis:

the artist is a relatively modern figure. It is certainly true that the conception of the artist as 
unique and gifted individual is an historically specific one, and that it dates from the rise of the merchant classes in Italy and France, and from the rise of humanist ideas in philosophy and religious thought. over the next couple of centuries this concept narrowed and sharpened, and the artist (or writer) was increasingly conceived of as a person with no institutional ties whatsoever (Wolff, 1981:27).

Robert Kelly has described how museums function as status symbols. The traditional status symbol system based on wealth and status objects has been eroded with the more equitable (relatively) distribution of wealth and objects that has occurred in this century. The resulting ambiguity has led to a search for symbols that are, according to Kelly: not based on wealth alone, that are incorporated in a system that must be readily recognized as such by those for whom they are appropriate, that are difficult to counterfeit, that are socially visible, that can be passed on from one generation to the next, and that are consistent with the basic values of the society (Kelly, 1985:16). Museums, and especially art museums, have ably filled this bill. There is thus a necessity to maintain the mystified and transcendertal conception of art in order to maximize the status symbolling qualities of art museums. If art and art museums were to be socially and historically located, and this location generally understood by the populace, this status balloon would be seriously deflated. Gramsci has also written of the importance of prestige and cultural life for the dominant group's maintenance of hegemony (Bennett, 1981:197, 213). The transcendental view of the nature of 
require bourgeois appropriation. It is already thusly socially located. The art museum as a status marker, it will be arqued, is a significant symbolling domain of docents, a cornerstone of status display. In the following section, through reference to the museum education literature, the training and work of docents will be discussed, along with an analysis of motivation, and the articulation of volunteerism within the social structure.

THE TRAINING AND WORK OF DOCENTS

We have seen how the act of volunteering in a publicly funded museur such as the Elgin County Pioneer Museum can serve as a demonstration of proprietorship. This demonstration is effected through displays of selfless devotion to a noble cause, the cause of communicating, in the case of the art museum volunteer, a passion for works of beauty. Volunteer docents ara communicants to a generally closed system of mystified and codified information about objects of social production. (The social production itself is not class specific, but involves factory workers to make paint, paper, canvas, wood frames, etc.) They have usually gained their knowledge of this system through their own family socialization to art knowledge, by following a university art history program, or by the means of the museum training programs that permit them their privileged position as communicators of the art word. 
the museum represented the slave-owning planters. Left out were the slaves, plantation labourers, peasant farmers, fishermen and orginal Amerindian population. This began to change in 1980 when a committee was established by the government to make recommendations regarding the museum's development, in order to have the museum function as "an instrument of national identity". In such a manner, "reality" can suddenly underço a remarkable transformation:

$$
\begin{aligned}
& \text { Museums are ... carefully created, artificially } \\
& \text { constructed repositories; they are negotiated } \\
& \text { realities... In short, museums are amenable to } \\
& \text { analysis as visual ideologies... (Cannizzo, 1987:22). }
\end{aligned}
$$

In brief, the Barbadian government wasn't in aqreement with the visual ideology presented in the museum, and this was "renegotiated" in order to reflect the government's conception of the history of Barbados. In Barbados, it seems, the museum wasn't reflecting the existing hegemony, but a previous one. The museum was to now serve as an "instrument of national identity", putting one in mind of the conception of the utility of Canadian museums as espoused by the Massey Commission and the National Museum Policy.

A critical look has also been taken at the work of Canadian community historical museums. Chris Miller-Marti has worked as curator of the oxford Museum in Woodstock and Ye Olde Museum in Beachville. Both these museums are located in Southwestern ontario. Frequently, such museums present the past in an idealized and romanticized form: 
The pioneer seems to live in an eqalitarian, conflictfree milieu and demonstrates the moral virtues of temperance, loyalty, hard work and goodwill... Absent are the signs of hardship and struggle for survival in a harsh climate, of economic inequality, or of class conflict... (Miller-Marti, 1987:37).

We are given a presentation of the past as it is thought to have been experienced by a rural and small town elite. It is a past where many of our own ancestors may have been farm hands, railroad workers and factory labourers. The pioneer utopia is recreated, however, for our vicarious enjoyment. It is a dreamland where all present-day social classes may enjoy tea and strawberry shortcake on the lawn, brought to us by faceless members of the lower orders. The fine furniture, glass and china, and idea of personal maid service, form a seductive symbol of life as it ought to be and as it must have been. It is an elitist and escapist re-creation, and one that legitimizes and naturalizes class based inequalities. It is a phenomenon that Richard Schechner terms "restored behavior":

Restored behavior offers to both individuals and groups the chance to rebecome what they once were - or even, and most often, to rebecome what they never were but wish to have been or wish to become (Schechner, 1985:38).

He sees such restoration of behavior taking place in pioneer villages, where role playing encourages the reinvention of the past into new scenarios.

In these museums, the artifacts of the lower classes are hardly present, and consequently not a part of museum 
interpretation. The passive collections' policies of such institutions are in part responsible. These museums accept donations but frequently do not solicit them. As a result, we find the history of social classes who are not alienated from the museum represented in displays and exhibitions through their objects which they have donated. In this manner, donations occasion an appropriation of the past through the cultural text that results. But donations consist of more than artifacts. They also consist of time and labour.

The Elgin County Pioneer Museum, located in st. Thomas, Ontario, was founded in the 1950's by two voluntary associations, the Women's Institute (WI) and the Imperial Order of Daughters of the Empire (IODE). They are both elite voluntary organizations, the former rural and the latter urban. Although their numbers have declined in recent years, they are still the driving forces at this museum (I worked as curator there in 1982 and 1983). They have majority representation on the Board of Trustees that runs the museum, and monopolize all volunteer committees. The museum, however, is owned by the county of Elgin and supported primarily by municipal and provincial tax dollars. Museum events are held when convenient to the WI and the IODE. A fund raising bazaar may be held on a Wednesday afternoon, thereby not attracting anyone doing factory work. Although the museum may be theoretically open to all, it is 
viewed, and in some cases feared, as an elderly ladies' museum. Volunteered artifacts and volunteer labour thus serve to establish and maintain proprietary rights on the world view of a publicly funded community historical museum. Can the National Gallery of Canada also be analyzed as the locus for elite practices? Can volunteerism at the Nat:onal Gallery be viewed as a discreet but effective appropriation of a publicly funded institution to class specific ends? One could begin to answer such a question by asking whether there is any further need for appropriation. Linda Nochlin, a professor of art history at the city University of New York, has written on the links between museums and radicals. "Radicals" have asked,

whether high culture is something you want to preserve at all. Is it just simply completely a rarrier of aristocratic or bourgeois values?... s.. ne of that (philosophy) certainly inspired the art politicians of the 1968 revolutions, who again wanted to get rid of high culture (cited in Cannizzo, 1982:6).

She describes the Louvre as the supreme symbol of high culture:

...it's a kind of secular church where one is supposed to come and worship, on the whole. People come from all over the face of the earth, it really is like the ultimate goal of a pilgrimage... like all pilgrimage shrines, the atmosphere there is one that is not conducive to criticism. You're not supposed to be negative or to analyze, or to ask negative kinds of questions, i.e. to ask about the ideology behind these works. The motivating impulse is worship or admiration (p. 6).

Art museums, because of, according to Nochlin, the primarily elite ideological content of their artworks and 
the former elite ownership of their objects, are probably the least democratized of all museums. Indeed, to observe their visitors is to sometimes feel that the former owners of collections have returned (Kelly, 1985). The new National Gallery, located on a ceremonial route of the National Capital, can be viewed as a secular church of worship. The entry colonade, modeled after a similar liminal space in the vatican, marks the transition from the profane outside world, to the sacred interior. Although an analysis of the building itself is beyond the scope of this chapter, and wili be considered in chapter 4, the architecture does make significant ideological statements. As Nelson Graburn remarks in "Museums and the Visitor Experience",

the edifices need not be old, but the aura cast by massive portals, high ceilings, and a reverential atmosphere must seem to endure unlike our commonplace homes and workplaces (Graburn, 1977:14).

In this context, he refers to "architectural expressions of grandeur and permanence" as "reassuring", although he later says that "the museum and its collections may be symbolic of oppression and deference". The manner of presentation of the objects in art museums- labeling, hanging, framing, encasing, also "sacrilizes" the objects and the institution. Both the building and the physical presentation play significant roles in constructing power relationships with museum visitors.

The art museum as an institution then, doesn't seem to 
require bourgeois appropriation. It is already thusly socially located. The art museum as a status marker, it will be arqued, is a significant symbolling domain of docents, a cornerstone of status display. In the following section, through reference to the museum education literature, the training and work of docents will be discussed, along with an analysis of motivation, and the articulation of volunteerism within the social structure.

THE TRAINING AND WORK OF DOCENTS

We have seen how the act of volunteering in a publicly funded museum such as the Elgin County Pioneer Museum can serve as a demonstration of proprietorship. This demonstration is effected through displays of selfless devotion to a noble cause, the cause of communicating, in the case of the art museum volunteer, a passion for works of beauty. Volunteer docents axe communicants to a generally closed system of mystified and codified information about objects of social production. (The social production itself is not class specific, but involves factory workers to make paint, paper, canvas, wood frames, etc.) They have usually gained their knowledge of this system through their own family socialization to art knowledge, by following a university art history program, or by the means of the museum training programs that permit them their privileged position as communicators of the art word. 
That seminal work of the art education field, "The Art Museum as Educator" (Newsome and Silver, 1978), devotes an entire chapter to the work of the museum volunteer. Group tours for schoolchildren are described as the staple,

but even these range from the conventional lecture... to the school visit combined with tour.... to some of the more elaborate programs found at the High Museum, where volunteers engage children in games, acting, musical performances, and art-making in school classrooms and at the museum. Docents also go out of the museum to schools and community centers, and in some places they help to design programs as well as carry them out. Depending on the institution, they may be qiven a good deal of responsibility (Newsome and Silver, 1978:243).

Obviously, attitudes have changed since George Goode's disapproval of attempts to provide art education to those in the larval stage of their existence.

The following description of docent programs at the National Gallery is not based upon intensive fieldwork. Such would be a fascinating study in itself, but one that would require the detail of a separate investigation. What is attempted is an examination of the Gallery's Docent Handbook in order to ascertain the likely gender and social class of docents. Comparisons are made with other museums based upon available literature on the subject.

At the National Gallery of Canada (NGC), there are three programs that volunteer docents participate in. The programs have been established by Education Services of the Gallery. The programs are intended to communicate informa:ion about the artworks on display at the Gallery. 
The NGC's Docent Handbook states that:

The purpose of all three is to quide tours of the Gallery's Canadian and European permanent collections. All three programmes use the same basic method, a dynamic one, that involves the public in thinking about and discussing the work of art. Understanding the objectives of the particular programme, each docent prepares and presents a tour in his or her own way, adapting his or her knowledge and methods to the particular group of visitors (National Gallery, $1984: 7)$.

The use of the 'his/her' gender fluctuation is but a convention. The art museum docent is overwhelmingly female. The literature on the subject, especially the docent handbooks, almost always uses the pronoun 'she'. The following is but a short compilation of gender specific references:

She is positively oriented to museum visitors, having volunteered for the job as tour guide, yet she may perceive that elements which she finds... (Speidel, 1978:6).

Should a docent be unable to meet her commitment, substitution arrangements... (Suthherland, et. al., $1979:$ H).

A Docent's best ally is her enthusiasm... (Cuthbertson and Wood, 1975:9).

Letters from children expressing appreciation for

museum tours are addressed "Dear Museum Ladies". If at times gender is rut directly expressed, it is implied:

"Purses may be left in the locked cupboard above the sink in the Junior Workshop"; "As a docent, always be gracious, a true host(ess) and sell the museum" (Cutherbertson and Wood, 1975:9). In describing processes of recruitment, the same handbook advises the reader to, 
visit various clubs to ask for representatives to work on your project. The Women's Institute, for example, is an organization concerned about the community, which supports various education programs in the province (Cuthbertson and Wood, 1975:3).

At the National Gallery, there are three proqrams involving the services of docents: elementary school tours, public tours and mini-talks. Elementary school tours are requested by teachers and arranged by Education services. Public tours are generally intended for adults and are offered at prescribed times. Mini-talks are also intended for adults. They consist of fifteen minute presentations on a specific work of art. They are regarded as preparation for the more demanding public tour. It should be understood that in general art museums take a minimalist approach to providing labelling and basic information on artwork, out of a belief that such will somehow interfere with the visitors' experience. In public tours, docents can fill this gap (Dobbs, 1990:217) to an audience limited in its knowledge of art (Hancocks, 1988:261).

The structure of the NGC docent program will be briefly described. There is no attempt to be critical here, but to simply provide a concise overview. Docents for the NGC are recruited from the National Capital Region. There are two separate units based on official lanquage. An interview conducted by an Education Services officer determines suitability. Candidates must be available for a minimum of two years, the first year consisting of training and the 
second of work in the Gallery. The ime commitment is demanding. Participants must be available for a half day every Monday and another half day for giving tours and doing research. There is the expectation of an interest in the visual arts and the Gallery, although knowledge of art and experience in education are not considered essential. With the elementary school tours program, docents are expected to have a background and interest in working with children. The first year of training is intended to familiarize docents with the collections of the Gallery. Touring techniques and methods of communication are also studied. There is individual coaching for docents having problems. on-qoing training is designed to provide a background for new exhibit:ons.

Docents recruited by the Gallery then, must have available to them weekday time - - two half days per week. Although a socio-economic profile of docents needs to be attempted, it is most likely that only women who have raised their families, and whose economic circumstances don't require them to work, will be available for volunteer work. Robert Kelly (1985) distinguishes two types of volunteers - - traditional volunteers (TVOs) and new volunteers (NVOs). He asserts that most volunteers come from the former group, and are characterized by an early socialization to museums and volunteerism. Social contacts, part of which may centre on the museum itself, may result in 
the formation of an "old girls" network. Marriaqes to males of what he terms, shared "symbolic estates" result. These males may require such socially useful volunteer enqaqements as museum volunteerism. The nature of such enqagements precludes conventional employment.

New volunteers on the other hand, are not socialized to volunteerism, art or museums, but gain some familiarity to the phenomena through university proqrams. They and their spouses do not have the symbolic estates of the TVOs, they are fewer in number in volunteer programs, and there tends to be a rapid turnover of personnel. Kelly observes that, "they neither necessarily believe they have an obligation to society nor especially enjoy being in museums" (Kelly, 1985: $31-34)$.

Although the internal group structure of docent organization at the National Gallery needs to be investigated, there are certain dynamics of normative group behavior that can be considered. As a high status activity, it has been noted how there are occupational co-relations to the social structure. Within the docent organization itself, however it is constituted, there will be norms of group behavior that will regulate membership. Thomas Bottomore has described the social dynammics of voluntary organizations in general:

Consciously or unconsciously some of the organizations discourage or squeeze out individuals with lower occupational status, either by fixing a high subscription, or by establishing a standard of behavior 
which is, or seems to be, unattainable by such individuals (e.g. one which involves frequent 'treating'). From the standpoint of the individual, a voluntary organization is seen not only as a means of satisfying certain of his [/her] interests or needs, but also as a group of people of a specific kind with whom he [/she] may or may not feel that he [/she] could mix freely (Bottomore, 1967:368).

within such voluntary associations, the ability to maximize status opportunities will be facilitated by having money and time to do so.

Given the rigorous time commitment required of docents, there must exist sufficient compensating enticements. Newsome and silver suggest that there is an exchange taking place - - training for labour. Docent training at the Boston Museum of Fine Arts cost $\$ 70,000$ in $1974 / 75$. The volunteer workforce certainly isn't coming absolutely free. Newsome and silver also cite the interesting social life, the satisfaction of service to the community, the attainment of prestige, and the eventual possibility of jobs (Newsome and Silver, 1978:243).

Robert Kelly has described a number of possible motivations for museum volunteerism: "a self-conscious obligation to do socially useful work (felt among the tradition-directed, socially privileged); 'invidious emulation'...; avoidance of the kept-woman designation conferred upon non-employed, married women by the feminist movement -volunteers are working, even if they are not paid; access to the back-stage in a museum -- this is symbolically much stronger than 'just visiting'; being a museum volunteer 
is a public (i.e. socially conspicuous) declaration of the quality of one's leisure and of disassociation with the working class where, at present, both spouses must work to assure economic survival; being a museum volunteer of fers the opportunity for one to develop specialized knowledge concerning and access to museum-authenticated markers that connote symbolically significant experiences"; and simple enjoyment of museums and museum work (Kelly, 1985:30-31).

As rewards for docents, the National Gallery Docent Handbook lays emphasis on the acquiring of new knowledge, and being a part of, "an active and friendly group". Further enticements include having access to the Gallery's library, the docent library, the slide library, curatorial files, curators and research specialists, gallery ID cards, a $25 \%$ discount at the Gallery Bookstore, a charitable donations receipt in lieu of providing parking, social occasions, and organized trips to other art museums. The first four rewards imply the gaining of insider, "backstage" knowledge of the gallery. This knowledge is extremely useful as a status marker, as is the ability to discuss art, and the material manifestation of both-the Gallery ID tag. Worn on a chain with the docent's photograph and Gallery logo, it is not readily distinguishable from those worn by paid staff members.

Although the NGC Docent Handbook states that, "Volunteer docents are much appreciated by both the children 

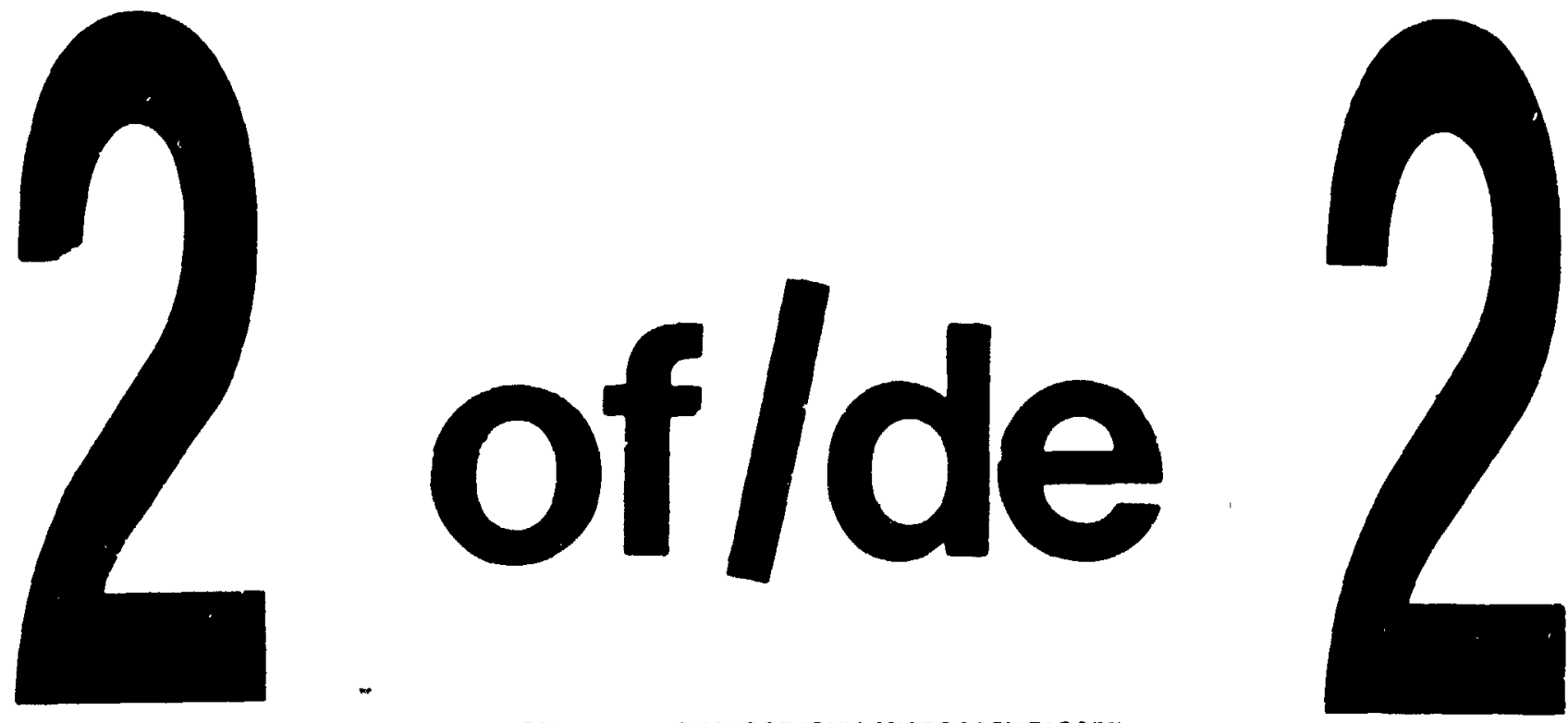

PM-1 31\%2" $\times 4$ " PHOTOGRAPHIC MICROCOPY TARGET NBS 1010a ANSI/ISO \#2 EQUIVALENT

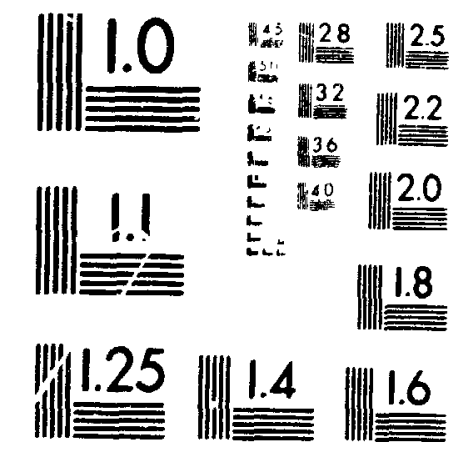

PRECISION ${ }^{\text {SM }}$ RESOLUTION TARGETS

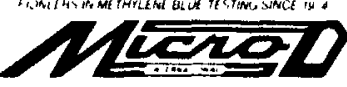

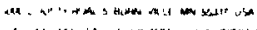


and the adults who visit the Gallery, by Education Services and by the entire Gallery staf $:$ " (NGC,1984:17), there are difficulties in such programs that are acknowledged by edcucators working in the field. Newsome and silver note tensions between volunteers and professional staff, resentment by educators that their domain is singled out for volunteer labour. Some volunteers can be irresponsible because the normal sanctions of paid employment don't apply. Power situations have been noted to develop because volunteers are of the same social group as trustees:

volunteers can be the most powerîl group in a museum. Their access to power has been demonstrated often enough so that a number of museums have resorted to specific schemes to 'control' their docents (Newsome and Silver, 1978:244).

Cases have been documented where docents have taken over education programs, and where the docent orqanization's primary function was one of social club (Bay, 1974:25). Docents can also be a problem if the museum wants to serve other social groups. As one educator remarked, docents are overwhelmingly white, female, and well-to-do. How... can these Ladies Bountiful hope to 'relate' to the poor, inner-city, and minority audiences that museums are now trying so hard to reach?" (Newsome and silver, $1978: 244$ ).

Another observer noted that, "the middle-class museum docent teaches a concept of art that militates against art. Art is not neat and clean" (Newsome and Silver, 1978:245). Nelson Graburn speaks of docent work as crucial, because the majority of the public find the art reception 
experience too much like work. Typically, he stops short of locating the varicus audiences to which he is referring, and one can only surmise:

Like dramatic actors, or teachers, they (docents) carefully manage their output, drawing out the visitors according to their type, adjusting their language and humour to the visitor... The visitor audience is a 'captive' group, and wants to feel that they are still 'in charge' in the task of 'making sense' so that the fragmented memories of the event will fit in with and illuminate, possibly restructure, their understanding of the world (Graburn, 1977:20).

Is one implication then, that they, the audience, are not in charge, and the experience must be constructed so as to trick them into thinking they are? Is this then the act of being, "an instrument to bring it out of the public"? Michel Cheff, during an interview, referred to the socratic method of questioning employed by docents: "It is where the public gets the most satisfaction. They will feel that they were capable of reacting to and thinking about works of art" (Grant, 1987, personal interview). It is hardly a balanced process, where art messages are raised from a knowing public. The structuring or re-structuring of the world occurs according to a prearranged power relation:

Ideas and beliefs are not transparent, but always originate in and conceal social structures and processes. It is the task of sociology to disclose these, and in this way to demonstrate the way in which communication is in fact 'distorted', because it is based on unequal relations and structures of power in society (Wolff, 1982:105).

The mystic notion of bringing out the knowledge is an idealist falsification of convenience to those interested in 
perpetuating a mystified notion of art. Art museum docents play a role in this process through their position as the socially sanctioned communicants of art knowledge. Their institutional and socially privileged position permits them to function as guardian angels of the Gallery and of the 'high' culture contained within. Gramsci has pointed out the need to determine the relationship between ' $h$ igh' culture and its utility in " 'cementing' complex forms of leadership" (Bennett, 1981: 192). The volunteer "proprietors" of the National Gallery also "own" the word. The message and the messenger may be one and the same. The message and the messenger form part of a hegemonic class' ideological "cement". The one legitimizes the other.

Federal policy, it has been noted, has not been required to support such forces of cultural homeostasis. The elite view of "high" culture is an assumption of the MasseyLevesque Report with its interest in the development of a refinement of taste. The National Museum Policy attempted to counteract the hold of elites on national and nation-wide cultural institutions through their democratization. As Gerard Pelletier remarked:

... it would be unfair to promote cultural activities that are reserved for the happy few (Pelletier, $1972: 4$ ).

This tension between the role of volunteers in assisting cultural homeostasis and attempts by policy makers and others, including museum staff, to democratize museums 
has its parallel in the activities of museums. An art museum such as the National Gallery can mount exhibitions in the tradition of Art and it can also produce exhibitions of contemporary Canadian video that challenge these traditions. In the following chapter, the role of the Gallery in providing culturally transformative experiences will be examined. 
CHAPTER 4

THE NATIONAL GALLERY VIDEO ROOM: A CULTURALLY TRANSFORMATIVE SPACE

In Chapter 3 I attempted to analyze elements of volunteer work in museum education. Individuals whose selfpresentation was often that of the selfless and devoted volunteer, were seen to be socially located persons with a fairly orthodox conception of art. This conception involved seeing the artist as inspired genius working in isolation from social and political constraints (Wolff, 1981:27). Similarly, the museum was viewed as a neutral, apolitical context for Art. This conception, reinforced by the worshipful atmosphere of the art museum, permitted the accumulation of cultural capital by docents who already belonged to an economically and socially endowed group. Connections were drawn between a dominant group's need for prestige in supporting hegemony and the prestige that could be derived by volunteer work in museums and the consequent association with an elitist conception of "high" Art. Such a conception/ideology of art was viewed as being reproduced by docents within snciety. Because docents are frequently the only point of human contact between the public and the museum, they are able to exert a "proprietary" influence over a theoretically public institution and its symbolic meaning, and make the National Gallery (or a local community museum for that matter) an effective apparatus of hegemony. 
This conception of museum volunteers was achieved through reference to secondary sources within the museum education literature, personal experience in museum work and an examination of aspects of volunteer work at the National Gallery. Although this process is a significant phenomenon in many art museums, in this chapter, my second case study, I want to consider a countervailing phenomenon - that of liminality, the state of being betwixt and between. With the assistance of the anthropologist Victor Turner's formulations, it is possible to analyze the National Gallery as a liminal cccurrence in its architecture, spatial arrangements, exhibits, program, etc. In this chapter, there will be a consideration of the liminality of the video room of the Contemporary Galleries in the light of its presentation of potentially subversive ideologies. This became strikingly apparent in the summer of 1988 when controversy erupted over the content of the exhibition: "Recent Acquisitions: New Works by Canadian Video Artists". Canada wide newspaper articles discussed the "pornographic" videos that were playing at the Gallery. Those videos whose subject matter dealt with alternative sexualities seemed to offend the most. In my view, this whole event was an engrossing demonstration of how a public and national institution could serve a liminal function. In the following section, I will follow Turner's writings on liminality, and consider their importance and usefulness for 
the analysis of aesthetic genres. The next section will outline a brief history of video at the National Gallery. I want to then look more closely at the most discussed of the controversial videos - Richard Fung's, "Chinese characters". A description of the controversy follows, with an analysis of its implications. In this analysis I will demonstrate how Turner's ideas make certain museum practices understandable. These practices are partially the result of federal policy, partially a result of museum workers' understanding of what constitutes their work. Turner assists us in understanding the museum as ritual space wherein both the forces of cultural homeostasis and the forces of cultural change are present. Such contradictory forces create tensions within the museum and tensions between museums and the surrounding society. These tensions, I will argue, are sometimes resolved by cultural change and the emergence of a new ideology.

\section{VICTOR TURNER AND LIMINAL PHENOMENA}

Writing in 1908, anthropologist Arnold van Gennep, described how the "life of an individual in any society [consists of] a series of passages from one age to another and from one occupation to another". He described such periods as being accompanied by "rites of passage" which he subdivided into "rites of separation, transition rites, and rites of incorporation" (van Gennep, 1960:2-3). He used the 
word "liminal", derived from the Latin word "limen", meaninc; threshold, to describe those rites occurring during the transition stage. Liminal rites mark, for example, the passage from boyhood to manhood. The Sambia of the Eastern Highlands of New Guinea believe that certain rites must be practiced in order to correct what is considered to be the feminine origins of boys. They are consequently removed from the villages and women for a ten to fifteen year seclusion in forest lodges. Initiation rites include:

1. tanning of the skin to remove female contamination: 2. nose-bleeding for internal purification; 3 . ingestion of male-identified plants and ointments; and 4. fellatio practiced as regularly as eating with as many partners as possible (Adam in Blackwood,1986:27).

Separated from the rest of their society, the boys in the forest lodges are freed from the customary categories and obligations. Turner saw the release from normal constraints as the essence of liminality. It made possible, he said, "the deconstruction of the 'uninteresting' constructions of common sense..., into cultural units which may then be reconstructed in novel ways". While, "some symbols must accord with the 'manifest' purposes of the ritual... others have the 'latent' capacity to elicit creative and innovaiive responses from the liminars and their instructors" (Turner, 1985:160). Here it should be noted that Turner is not using 'ritual' in the rigid and obsessional freudian sense. He sees ritual as a potentially rich and creative moment in social process. 
In small scale societies, Turner viewed liminality as providing the cultural means of soducing variability in addition to ensuring continuity. To him, liminality formed part of an adaptive strategy, that, through the maintenance of a repertoire of alternatives, enabled a society to possibly deal with drastic ecological or social change. He noted that some societies may appear to be strong because their religious systems and rituals are backed by superior political force. Such societies may in fact be potentially weak and prove less adaptive to change. Totalitarian social systems don't permit the maintenance of a repertoire of variant cultural models to facilitate adaptation (Turner, $1985: 162)$.

When Turner adjusts his analysis to a consideration of complex urban societies, he alters his terminology. The 'Iiminal' becomes the 'liminoid':

In these (the folk and high culture of complex societies) they find that the obligatory rituals and ritualized bonds characteristic of complex, rurally based civilizations have been supplanted by city-based associational and professional linkages. The dismemberment of ritual has, however, proved the opportunity of theater in the high culture and carnival at the folk level. A multiplicity of desacralized performative genres have assumed, prismatically, the task of plural cultural reflexivity. The... [dismemberment] of major liturgical systems, or, in some cases, their relegation to the periphery of the social process, has resulted in the genesis and elaboration of esthetic media... Song, dance, graphic and pictural representation, these and more, broken loose from their ritual integument, become the seeds of concert music, ballet, literature and painting. If ritual might be compared to a mirror for mankind, its conversion to a multiplicity of performative arts gives us a hall of magic mirrors, each reflecting the 
refections of the others, and each representing not a simple inversion of mundane reality, but its systematic magnification and distortion, the ensemble composing a reflexive metacommentary o.n society and history as they concern the natural and constructed needs of humankind under given conditions of time and place (Turner, 1985: $166)$.

In this essay Turner continues to knit the various elements of his analysis. I continue to quote in full:

A great opportunity is opening up for scholars in both social sciences and humanities who are interested in the reflexive or dialectical relationship between common sense processes in the "getting and spending" (biocultural-ecological) dimensions of sociocultural life and the popular and high performative genres which continually scrutinize, criticize, subvert, uphold, and attempt to modify the behaviour of the personnel, their values, activities and relationships, centrally concerned with the maintenance and management of those processes: or which make statements, in forms at least as bizarre as those of tribal liminality, about the quality of life in the societies they monitor under the guise of "entertainment" - a term which literally means "holding between", that is, "liminalizing" (Turner, 1985:166).

It is my intention to take advantage of one of those opportunities referred to by Turner, by examining the liminoid phenomenon of the video room of the National Gallery. The analysis will follow and extend that of Turner's by considering video as an esthetic genre of a complex industrial society, a genre that scrutinizes, criticizes, and attempts to modify the accepted norms of Canadian sociocultural life. Although Turner doesn't question why certain cultural activities are considered "high" and others "popular", it is possible to make reference to the work of Bennett and his interpretations of Gramsci for such an understanding. Bennett finds that 
Gramsci

enables us to ask questions about why, historically, a certain cultural form was considered to be 'low' or 'high', what effects this sort of division had and how it is reproduced today (Bennett, 1981:192).

With reference to Gramsci, we are thus able to make use of Turner's understanding of the place of ritual in culture change within class societies where a state hegemonic apparatus such as the National Gallery may also act, in contraction, as an institution of subversion.

VIDEO AT THE NATIONAL GALLERY OF CANADA

The following information was collected during an interview with Susan Ditta, assistant curator of video and film at the National Gallery of Canada.

The National Gallery of Canada has the only permanent video gallery in Casada, as well as the only full-time video curator. The collection, the largest in the country, consists of over 400 tapes. Video programming began at the Gallery in 1977 when free-lance curator Mayo Graham was hired to curate the video component of a survey show of contemporary art called "An Other Dimension". The Gallery subsequently bought all of the video works from that show. Later, Bruce Ferquson, who was assistant curator of contemporary art, chose to present video as Canada's participation in the 1980 Venice Bienale. The theme of the Bienale that year was "The Rebellion of the Younger Generation". Rob MCFadden, a curatorial assistant to 
Jessica Bradley, herself assistant curator of contemporary art, started buying video regularly in 1981, and organizing video programs. In late 1983, the Gallery opened a regular video viewing room, but by Christmas of the following year the program had been shut down, officially because of a person year squeeze. There was an outcry from video artists, critics, curators and patrons but the program was not reinstated until funds became available at the time of the construction of the new Gallery. Susan Ditta was hired in May of 1987 as the first full-time curator of video and film.

Part of Susan Ditta's mandate was to design and integrate a video viewing room into the contemporary qalleries of the new building. Other institutions had tended to displace video viewing rooms to remote areas of a building because of the noise and the potential for controversy. At the old Lorne Building, videos with this potentlal were shown on Thursday evenings when the larger public was the least likely to see them. At the new National Gallery, the decision was made to give the video room greater prominence. This necessitated some special design considerations regarding the conflicting needs of accessibility and sound proofing. Max Dean, an Ottawa artist and teacher, was hired to work with curators and contractors for the fit-up of the room. This involved the design and selection of doors, signage, carpeting, seating, 
etc. Ms. Ditta wanted to create "a public space feeling, like a library". yet one that was intimate and comfortabie. She did considerable research to that end. She considers video to be a personal and exploratory medium that is problematic when placed in a gallery context that idealizes and sanitizes art. She hit upon the idea of usirg a red neon "Video" sign that would counter these contextual influences. She wanted "something funky that related to video's roots in the real world", but had to fight to get it. Both the Gallery's and architect Moshe Safdie's designers were against it. The head designer was ill the day the sign was approved.

Visitor comments from the viewing room at the former Gallery had been mostly negative. She felt that this showed that the public needed more information: "If it (the video) doesn'c luok like an American sit-com people don't know how to read it." She therefore decided to use didactic panels for the new video ruom that would provide more contextual information - an artist's statement, a photo of the artist, biography, and a still from the tape. A bookshelf was also provided, with publications on video.

What has resulted is a room unlike any other in the National Gallery. Two large glass doors separate this room from a larger one. A neon "Video" sign on the other side of the doors arouses curiosity. One literally crosses a threshold in order to enter a youm of intimate proportions 
and reduced illumination. Three banks of fixed comfortable chairs face video monitors. Didactic panels line the wall where the entry doors are located. The panels receive iilumination from overhead lighting and a window. There is a sensation of being in an institutional living-room. The monitors, which play a program fixed according to a prearranged schedule, promise "entertainment" of varying sorts according to the previous experiences of the visitor. The room is, physically, technically and psychologically, a liminal space.

RICHARD FUNG'S "CHINESE CHARACTERS"

The video that was most discussed during the controversy of the summer of 1988, was Richard Fung's "Chinese Characters". This 1986, 30 minute tape is described in the flyer that accompanied "Recent Acquisitions: New works by Canadian Video Artists" as follows :

Chinese Characters unfolds around the telling of an ancient Chinese myth, the story of a young man on an odyssey to find the source of the Yellow River. This journey becomes a metaphor for the artist's search for a gay Asian sexual identity in a world dominated by images of white gay porn. Fung's work provides a critical reinterpretation of the construction of male desire that challenges definitions constrained by class and race. The tape is a graceful mix of film clips, fantasies and staged interviews that stands in contrast to and in conflict with "classic" Chinese imagery. The tape begins with a quotation from Confucius: "Food and Sex are Human Nature". Accompanied by traditional 
Chinese music and visual imagery, the narrator, in the section entitled "East", tells the story of wai Tinq, who was sent to find the source of the yellow River, a place reputed to contain many riches.

Such journeys themselves can be viewed as liminal phenomena. Two distinct periods are demarcated. There is the normalcy of the period before departure, that, in the case of "Chinese Characters", is presented in the introductory narrative. The journey itself, which has aspects of a pilgrimage, can be seen as a special altered moment of experience. One cannot know for sure what may lay ahead. The narrator speaks of dragons and other unforseen dangers. Victor Turner identifies pilgrimages as liminal phenomena, characterized by a "rearrangement of thought patterns" (Turner, 1974:168). We thus experience mounting levels of liminal experience. Situated in a liminal space the viewer experiences a liminal esthetic genre, and sees and hears of a journey that itself has liminal characteristics.

Suddenly, the video cuts to a contemporary chinese man who is getting dressed to go out, perhaps to the bars, perhaps to find the source of the Yellow River. Disco music plays in the background as well as a voice over that describes the hot action from a certain company's porn collection. There is then another cut to an interview with a male of Asian origin, who describes his exposure to gay 
porn magazines. Beside him a video monitor displays scenes of chinese architecture.

The scene again changes to show wai Ting on his journey. Movement is portrayed through the presentation of legs that are variously dressed - sometimes with traditional Chinese apparel, other times with contemporary bar outfits. This series of contrasts is sustained throughout the video and serves to accentuate both cultural continuities and discontinuities, and cultural change.

During another interview scene with a male from Malaysia, the video monitor shows a naked nan fondling himself. The interviewee speaks of how "porn increases [the] ability to fantasize". He relates how porn "nelped [him] to become more free".

It is in this manner that the preconceived thought patterns of many visitors are challenged. Gay sexuality is not only presented as part of the ordinary lived experience of individual actors in the video, but the artist dares to see positive elements to pornography.

The section of th: tape entitled "West" received the most media attention. Wai Ting, who continues on his journey, has a simulated, and quite funny, woodland encounter with Al Parker, a well known and well endowed star of American porn films. Then, with an orgiastic background of gay, white, California style blond and bronzed males, voices ask questions and make statements - "So where are you 
from?"; "Are you a foreign student?"; "But you look more Japanese than Chinese."; "I like Orientals!". They are the type of questions that white male canadians may ask in a meeting place such as a bar or party.

Wai Ting continues on his journey until he meets a young woman spinning threads of silk. She gives him a spindle with instructions to show it to the court astronomer. An Asian irdividual is then shown being interviewed about sex and "talking dirty" during sexual relations. He relates that he picked up "talking dirty" from straight porn, and without a chinese accent. He asserts that porn has a role to play in showing us what is desirable, although he also wonders how much of his Asianness he is denying by following the images of the gay white maleness being presented. This seems to exclude Blacks and Asians as desirable people. During this discussion, a video monitor shows a man sucking his own big toe, sniffing socks that are held to his head by eyeglasses, and wearing underwear over his head, all while "talking dirty" and simulating sexual ecstasy. The combinations are very humorous.

Further discussion in a section of the video labelled "South" refers to growing up in the West Indies (Richard Fung was born in Trinidad) and being the object of racism. stories of China told by parents and a book received as a present, helped to soothe hurt feelings. The book related 
the story of an explorer who discovered that the source of the Yellow River was in the Milky Way.

The video ends with "Down There" and Wai Ting returning and showing the court astronomer the spindle. The old man points to the Milky Way. Images follow of a Black and a Chinese male embracing, and a suggested sexual fantasy with the captain of an airplane - "anything I can do to make your flight more enjoyable?".

THE CONTROVERSY

on the flyer accompanying "Recent Acquisitions: New Works by Canadian Video Artists" video art is described as "different from most of the other works in the National Gallery. It is not an object. It is time-based. It interrupts the pristine nature of the museum with a cacophony of sounds, colours, images, technologies and voices." This first show was intended, according to curator Sue Ditta, to be a survey show of contemporary Canadian video production, but it was recognized that there could be a problem with the sexual content of some of the works. The matter was discussed between Sue Ditta, Diana Nemiroff, associate curator of contemporary art and Brydon Smith, assistant director of ccllections and research, and it was felt that it would amount to a falsification to segregate some of the material, because the whole purpose was to do a survey show, and not a theme show. It was decided to place 
a sign on the doors of the room informing the public that there was sexually explicit content to some of the videos. There were no objections from artists over this decision. According to Sue Ditta, in the first week of the program there were three complaints from individuals who had not seen the sign and had taken children into the room. There was no other problem until a male student, aged 19. complained to the ottawa Citizen. The arts reporter sent to investigate, Nancy Baele, warned Susan Ditta that the editors were "looking for a story". Even though the reporter filed a longer article that was carried by the wire services, with three persons who she interviewed opposed to the videos and three in favour, editorial manipulation resulted in the sensational story that appeared on the front page of the August 11, 1988 Ottawa Citizen: "Pornographic' videos offend National Gallery visitors". In the story, the reporter is presented as interviewing a 19 year-old ottawa Lusiness student whose reaction to viewing Richard Fung's "Chinese Characters" was one of shock: "I couldn't believe they would show such material in the National Galle'y. The video showed close-ups of male genitals and intercourse between males. I'm fairly liberal minded but at that point I left in shock... In my estimation, that video is hardcore pornography." An Aliverta resident is also presented as being shocked by the scenes of masturbation and homosexual sex, and with moral indignation raises the spectre of the waste 
of taxpayers" dollars: "If people want to watch that sort of film in their own home, fair enough. But the National Gallery is an open space and I don't think taxpayers should be paying for pornography that very young people have access to."

In the citizen article, a persevering reader would discover an unoffended visitor on the inside pages of the newspaper. Here, a woman from New Hampshire is quoted as saying: "I think any parent who brings a child into the video room has been given ample warning, and should be prepared to leave if the subject matter isn't suitable."

The story was carried Canada-wide. The content remained much the same for various newspapers, although the selection of headine varied considerable. The following is a sampling:

"Explicit videos shock gallery goers - Exhibit not pornography, National Gallery says" (London Free Press, August 12:B11)

"Video art shocks viewers" (Globe and Mail, August $12: A 14$ )

"Le Musée national accusé de porno" (La Presse, August 12: C1)

"Visitors claim National Gallery videos are porn" (The Gazette, August 12:A7)

"Gallery accused of obscenity" (Winnipeg Free Press, August 13:22)

"Explicit video is pornographic, say National Gallery patrons" (The Edmonton Journal, August 12)

"Sexually explicit videos draw ire of gallery patrons" (Calgary Herald, August 12) 
"National Gallery videos criticized as porn"

(Kitchener- Waterloo Record, August 12:C6)

"Explicit homosexual video considered art at National Gallery" (Montreal Daily News, August 13:27)

"Les <<clips>> du Musée national: art ou porno?" (Le Journal de Montréal, August 15:38)

Jepson labels gallery videos 'pornographic'- Fuss played down by art officials" (London Free Press, August 13: A4)

Other media were also involved. Both television and radio carried the story - CBC Newsday, Ottawd: CKBY-FM, Ottawa; CJSB Radio, ottawa; CKCU, ottawa. Several lettersto-the-editor resulted, as well as an editorial in the Ottawa citizen. A letter writing campaign was launched by "Human Life International", a right-wing Catholic organization that keeps its followers aware of offences to the social order. The whole episode captured national media attention for just a few days, with letters-to-the-editor continuing on into september, but it is highly unusual for a gallery to attract such attention. The National Gallery had not done so since its opening in May. The controversy received more mass media attention than the Degas exhibition, the high profile exhibition with which the gallery opened. Coverage of museums and galleries is usually confined to the entertainment sections of daily newspapers. Many readers give these pages only scant attention. The controversy over the video room at the National Gallery thus became a national social drama, that, it will be arqued, became a national liminoid phenomenon, facilitating what 
Mouffe has termed sorial "disarticulation-rearticulation" (cited in Bennett, 1921:231).

\section{ANALYSIS OF CONTROVERSY}

victor Turner describes social dramas as occurring "wlthin groups bounded by shared values and interests... and having a real or alleged common history. Their main actors are persons for whom the group which constitutes the field of dramatic action has a high value priority" (Turner, 1982:69). Social dramas are a "spontaneous unit of social process and a part of everyone's experience in every human society". They have, according to Turner, four phases breach, crisis, redress, and either reintegration or recognition of schism. In what follows, the controversy over the content of videos at the National Gallery, will be analyzed as a social drama that created a national liminoid experience. This experience, it will be argued, permitted the Gallery to function as a potential agent of social and cultural change.

The breach phase of the social drama involving the video room of the National Gallery was initiated by the ottawa business student. The compliance of the ottawa citizen was required in order for the story to gain prominence. The Ottawa citizen may have been interested in reestablishing social orthodoxy or it may have just been looking for a "good story". The resulting crisis involved an acting out 
of the drama by several important actors representing various interests. Turner refers to these as, "star groups," and defines them as, "groups to which we owe our deepest loyalty and whose fate is for us the greatest personal concern" (Turner, 1982:69).

The content, or alleged content, of the videos at the National Gallery, constituted the subject matter of the social drama. The resulting Canada-wide newspaper commentary provided a liminoid experience for the Canadian public, and, in the end, a recognition of social schism. The elements of this social drama will be considered in greater detail in what follows.

The dramatis personae of the social drama as evidenced by the media include the following: Susan Ditta, representing the artistic and gallery community; Richard Fung, the artist, who is wrong or wronged, depending on one's point of view; Jim Jepson, the member of parliament representing an outraged and moral public; and Cory $\mathrm{O}^{\prime} \mathrm{Neil}$, the ottawa business student who caused the breach. He declares himself liberal, but knows where to draw the line. The drama was acted out nationally over the questions of what constitutes art, what art is appropriate for the National Gallery, the corruption of youth and the maintenance of tradit;onal values, the legitimacy of homosexual expression and whether the Gallery should be a vehicle for such expression, and even the safety of women 
and children. On the one hand individuals of social

orthodoxy such as Jim Jepson, Conservative MP for London

East, maintained that the videos had blackened the image of the National Gallery. Mr. Jepson was a major figure of the redressive machinery. After calling the videos "garbage" in the House of Commons, he said:

They are demeaning to its image... they really detract from what I believe is a beautiful building... Too much freedom was being taken with art at society's expense. Where is the artistic merit in masturbation? Holy smokes. In terms of society trying to keep reasonable values this only confuses the situation. When you show homosexuality as art, are you not seen as accepting that value? (London Free Press, August 13: A4).

When interviewed by $C B C$ reporter Erik Sorenson for the program, "Newsday," Mr. Jepson was angered by the Gallery's position of being at arm's length from the federal

government:

I just can't see how there would be any artistic merit, indeed any redeeming value in something like that and $I$ think it's high time that this defence of artistic merit be looked at seriously (Media Tapes and Transcripts, Auqust 11, 1988: 2).

Participants in Human Life International's letter writing campaign (many letters were directed to Communication's Minister, Flora MacDonald), concurred with many of Mr. Jepson's opinions. The following is a sampling of comments, all of which are direct quotations:

brought the lovely gallery into disrepute, it will soon be a laughing stock, you (Sue Ditta) have brought smut and pornography, you are doing untold harm not just to individuals, but to Canada: (the curator) should be let go or given another job where her tastes will not damage our young Canadians; depraved videos... distort 
the public's concept of what are normal human sexual relationships... lewd, obscene, unatural (sic) homosexual acts such as sodomy, masturbation and scenes of male genitals, an erect penis, and an anus etc.; Every time anyone buys or rents these films means encouragement for the pornographist to produce more and so influence more people to pollute the quality of life, and destroy the safety of women and children; Please (Flora MacDonald) help get this garbage out of our ART Galleries - PS, Just visited your beautiful city. Please keep it beautiful + CLEAN; As a Canadian Citizen who shares serious concern for "AIR POLLUTION, SOIL POLLUTION and MORAL POLLUTION"... I must make a formal protest over current report of "Pornographic Videos": In my opinion there is only one kind of sex that can be called "art"... that done within traditional marriage, in private! Any sex performed for public consumption is pornographic (National Gallery letter files).

Sue Ditta felt that most of the above individuals had never been to the Gallery, but had simply responded, either to the appeal from Human Life International or to the media coverage. Many of the letters arrived in envelopes with drawings of the Virgin Mary or slogans denouncing abortion. One letter even arrived with the form letter appeal from Human Life International.

The strong denunciation of the polluting effect of the video by two letter writers is interesting. In small scale societies individuals involved in liminal phenomena are regarded as potentially polluting. Victor Turner notes how the unclear is regarded as unclean:

transitional beings are regarded as particularly polluting, since they are neither one thing nor another; or may be both: or neither here nor there; or may even be nowhere... (Turner, 1967:97).

Individuals involved in video production and presentation seem to share this distinction. In ancther 
esthetic genre, that of theatrical performance, it has been the female actress that has long been regarded with suspicion.

Several phone calls were received that followed similar patterns of thought as the letter writing campaign. One caller felt that the Gallery should show only normal things and that homosexuality is sick. Another felt that homosexuality is "perversive". Neither of these two individuals had seen the videos or been to the Gallery. Another caller said that there were lots of nice Chinese girls in ottawa for Richard Fung and wondered if Shirley Thomson (director of the Gallery) was Canadian. A male caller felt that curators' opinions don't matter and that Sue Ditta should be fired, and, no, he had not seen the tapes.

The above opinions are felt to represent a certain pan Canadian social orthodoxy. Catholic or Protestant moral teaching in general condemns the public depiction of sexuality and especially of homosexuality. For this group AR'r is not to be found on the video screen and possibly not in the contemporary galleries. This group was horrified that it was possible to present such images in a public place, and especially at that recently constructed monument to art, the National Gallery of Canada. And thus, not only was a dominant conception of art challenged, but within a subversive conception of art a dominant conception of 
sexuality was also nationally challenged.

In the other camp, a number of individuals wrote

letters, or letters-to-the-editor in support of the

presentation of videos with such content at the National

Gallery. Some were artists or from the video production

network. A selection of their comments follows.

In a letter to Keith Spicer, editor of the ottawa

citizen, Lisa steele, president of the Independent Film and

Video Alliance wrote:

Why have you allowed your newspaper to continue to hound and threaten Canadian artists with the label of 'pornographic' whenever they dare speak of sexuality... since when are the opinions of two ordinary citizens allowed to circulate so freely on the front page of a major Canadian newspaper? (August 31, 1988:A9).

Mike Hoolboom from the Canadian Filmakers Distribution

Centre also wrote to Keith Spicer:

Painting has a long history of explicitly sexual subject matter. Sexuality surely remains an integral part of the human experience and its representation in art surely comes as no surprise. What should really shock viewers is the absence in the images that surround us of any means by which we are able to situate ourselves as ocher than passive media consumers of how we might be able to make our own images of our own lives (Ottawa citizen, August 30, 1988:A9).

A letter from John Greyson, a Toronto video artist, was published in the Globe and Mail on August 30. The following is an excerpt:

Richard Fung's widely acclaimed Chinese characters is singled out for this dubious honor lof being hardcore pornography]. Its complicated, multi-layered narrative explores difficult questions of socialization for gay Asian men within a gay subculture determined by white male standards. The tape's engagement of urgent debates concerning racism, representation and desire 
place it at the forefront of contemporary art practice, which is obviously why well-respected curator Susan Ditta chose it in the first place (p. A6).

One letter of support came from a female United church minister. Another, from a private individual, admitted to not having seen the videos, "but then, how many of those who hate 'The Last Temptation of Christ' have seen it, either? Isn't it wonderful to live in a world of opinion-by-report? Perhaps it explains the revival of God" (National Gallery letter files).

Shirley Thomson, director of the National Gallery, defended, in an August 18 letter to the ottawa citizen, the showing of "Chinese Characters":

The artist today, as always, holds a mirror up to society, and the gallery's mandate is to put the artist's work in a social and art-historical context, and to exhibit and explain the work and its relevance to us ( $p$. A9).

Flora MacDonald also defended the right of the gallery to decide on its own programming. All letters of complaint received the following statement from Anne Harris, her chief of staff:

Although Miss MacDonald is the Minister responsible for museums and galleries, she is prevented, by a long standing convention and the firm commitment of this government to the arms-length principle, from becoming involved in curatorial or artistic decisions made by cultural organizations within her portfolio (National Gallery letter files).

And thus federal museum policy assisted the Gallery in maintaining an independence in programming in spite of the ferocious criticism of a conservative party member. 
The main defendei of the artists, their video works and the video room, in the print media, on television, radio, and the telephone, has been Susan Ditta. She has arqued, frequently with humour, that the works and the imagery they contain must be seen in context. When interviewed by a CJSB radio reporter and asked, "Do these videos show homosexual intercourse?', she replied as follows:

Well I think it's really very dangerous always to set imagery outside of its context. I for example am looking at a picture right now that has two men in leather masks in a dungeon with large pliers snipping the nipples off a woman. Now if I told you that the... picture contained that, you might think it was a sadomasochistic pornographic scene from "Hustler Magazine." REPORTER: You have my full attention.

DITTA: Well in fact it's The Martyrdom of saint Agatha painted by Sebastiano Del Piombo in 1520 and it's a major piece in the Louvre Museum in Paris. I think that particular painting is certainly about religion. It's about sex and religion... (Media Tapes and Transscripts, August 11, 1988:2-3).

We can assume that the above very public manifestations also had their private counterparts. Beyond the actual duration of the video program, the content and its meanings were undoubtedly discussed at parties, in bars, Women's Institute meetings, meetings of the community of Concern, by artists, church and museum goers, across the country. There seems to have been some expectation among the adherents of social orthodoxy, that the show might be closed down. This would have been a demonstration of state coercive power at its most disrobed. Had the Gallery been forced to close the show, a social reintegration would have been achieved, and "traditional family values" would be viewed as reaffirmed. 
That the show wasn't closed down, but vigorously defended and legitimated by what Turner has termed "star groups", has led to a situation of social schism, where the right of the National Gallery to do such programming received justification. The perception of social schism, or at least of alienation from what is thought to be the "proper" role of the National Gallery, can be the springboard for both cultural change and the rearticulation of a new or at least transformed, ideology.

\section{CONCLUSTON}

It has been postulated that the architecture of the National Gallery prepares the visitor for a liminal experience. The entry colonnade permits the visitor to leave behind the everyday experience of the outside world, and enter a world of other experience. That other experience will vary considerably according to the social background of the visitor. It is possible to generalize that the non-contemporary galleries will tend to reinforce traditional conceptions of what constitutes art. The work of docents in these galleries will augment this perspective. Such conception. will be challenged by the contemporary galleries. The content becomes more ambiguously art, or in other words, increasingly liminal. This challenge / ambiguity / confusion is at its most extreme in the video room. The contemporary galleries are at least contained 
within an art framework, that, no matter how great the doubt on the part of the visitor, carries the contextual message that this is Art. The video room throws out the framework almost entirely. The room's neon sign, comfortable chairs, carpeting and darkness make ir: a museum and not a museum, a living room and not a living room. The TV sets promise "entertainment" but don't deliver it in the standard network format. When the visitor sees a video like "Chinese Characters" many references to previous experience may be lost: Is the art?; Is this popular culture?. In the confusion, the categories of everyday life are thus rearranged, and a new pattern is presented. This is precisely what Richard Fung wishes to achieve. In a review in the July/August 1986 issue of Cinema Canada, author Phil van steenburgh refers to how Fung takes issue with social conditioning and its manipulative power:

The images suggest an initial ambivalence to the quest for sexual identity, followed by accelerated intellectual postering. Towards the end of the tape, the adventurer finds the answer to his quest, as a court astronomer directs his gaze to the Milky Way, revealing it as the source of the Yellow River. The plethora of stars comprising the Milky Way seem to suggest a destination of a multitude of choices, of freedom sexual and personal (p. 27).

Fung and other video artists in their new constructions of the possible, and the National Gallery in its creation of space for the reception and the contemplation of it, are generating new cultural possibilities. This process is what Turner refers to as anti-structure - a latent system of 
alternatives (Turner, 1979:44). The social dramas that may result from the presentation of cultural variability are themselves healthy to the system and contribute to antistructural process. As Turner has remarked, they, "keep us alive, give us problems to solve, postpone ennui, guarantee at least the flow of adrenalin, and provoke us into new, ingenious cultural formulations of our human condition..." (Turner, 1982:111). In the end, the combined liminality of place, mediua and message in the National Gallery video room permits the maintenance of a repertoire of cultural alternatives that contributes to our strength as a society by providing the means to view and possibly to change it.

Federal museum policy and the principle of arm's length funding make such cultural activities possible. The Gallery still remains a multivocal symbol with elements such as the docents as discussed in the first case study, to ensure cultural continuities. The tensions, contradictions and contestations over values and meanings within the museum still have the potential of being anti-hegemonic and transformative. The ritual space that is the Gallery thus contains both symbols for cultural change and cultural continuity. As a hegemonic apparatus of the state, the Gallery affords expression to an articulation of a worldview of a dominant class through prestigious volunteer associations with objects of Beauty. As a potentially culturally transformative institution, the Gallery may allow 
a rearticulation of existing ideological elements. A new hegemony may be in the process of formation with a new element of a "cementing" ideology. 
CHAPTER 5

\section{CONCLUSIONS}

There is the quite valid perception among many observers of the museum profession (Kelly, Cameron, Cannizzo) that museums serve an ignoble role of providing a symbolic realm for those possessing power within a given political unit, to augment and legitimize that power. Museums thus viewed endow such groups with a shimmering mantle of influence over the interpretation of the past, present and future through an institutional base that ranges from historical museums to museums of contemporary art.

The analysis of the role and influence of volunteers at the National Gallery of Canada and at other art museums, supports such a conclusion. Docents have been viewed in this work as guardians of a certain transcendental conception of art in a theoretically public institution. They use their control of the interpretation of artworks to effect an undemocratic influence on the institution.

Federal museum policy such as the National Museum Policy of 1972, has at times attempted to democratize museums, to take them out of the control and service of "the happy few". Museums are, however, multivocal symbolling domains. The same National Gallery provides spaces for the contradiction of established forms.

The National Gallery video room has furnished an 
instance of challenge to conventional views of sexuality and sparked a national social drama over the legitimacy of qay and lesbian expression, the role of the Gallery in facilitating such expression and even the nature of what constitutes art. Museums can thus be sites of contradictory purpose. They are not exclusively forces of social and cultural conservatism. They can be sources of new culture by generating the means for societies to consider and possibly adapt to change through the visual and textual presentation of alternatives. One is thus able to extend victor Turner's conception of the role of the arts in complex societies to encompass the repositories of art and artifactual manifestations.

Federal government policy plays the role of providing financial support and ideological direction to museums. It has at times emphasized national unity, decentralization and democratization, museums as tourist attractions and contributors to economic progress, etc. Museum practices as a result of such policies may be directly perceived through such materializations as the National Museum Corporation's "Discovery Train" of the 1970s that carried the national unity message from coast to coast. But federal policy also sets the federal government at arm's length from its museums and other cultural agencies. Even though government members such as Jim Jepson vehemently disapproved of the showing of gay and lesbian videos, they were unable to exercise any 
control over the Gallery's cultural productions. Federal museum policy operates within a context of hejemonic structures. This paper has made reference to the work of Antonio Gramsci for an understanding of how museums function as apparatuses of hegemony. They have an important cultural role in educating consent, of permitting associations to "high" art and its consequent prestige that results in some ideological unity not only for the dominant class, but also for those dominated. Even the dominated can subscribe to cuturally authenticated definitions of what constitutes art. Even the dominated can believe in the value of government funding for art museums as non-visitors to these museums.* Leaders and led are kept together through such beliefs as the transcendant nature of art and the importance of the National Gallery to house it and the importance of docents to interpret it for us.

But the hegemonic apparatus that is the National Gallery also contains the seeds of cultural change through the "disarticulation - rearticulation" of ideological elements. The cultural continuities that the Gallery so effectively establishes for our uncritical acceptance are challenged from within. A sense of being different and apart, of self-awareness transformed into criticism is the basis for creating a new culture, a new hegemony. The museum policy (viewed as a segment of cultural policy) which supports these activities through funds and at times 
ideological direction, is itself a thicket of contradictions and is healthy and useful to cultural workers and to society as such.

There are, it would seem, useful messages here. Museum (and cultural) workers could benefit by a more selfconscious awareness of how their work articulates within social processes. Such an understanding may instill a greater sense of purpose and direction to museum work. This may lead to some doubt over the usefulness of the continuous display of heirlooms of the rich and famous of the last century. Displays of cultural conservatism do nonetheless form the basis of cultural continuities, and are not of themselves inappropriate and without some usefulness . Museum workers may also achieve satisfaction through the identification of social problems needing both historical contexualization and some greenwood of new cultural direction. They have within their policy making apparatus, their collections and their communities, the mearis to remain culturally reflexive and culturally innovative. The policy making apparatus must remain healthy through some balance of remaining at arm's length and providing necessary cultural direction without cultural dirigisme. Museun workers, on the other hand, require essential grounding in cultural and social process through anthropological, sociological and historical training if they are to supersede a role of cultural automatism, unthinkingly replicating archaic forms. 
The active role of cultural generator shuffles within us.

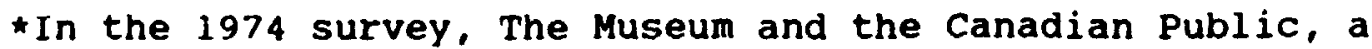
control group was asked if they approved of government financial support to a variety of activities:

A majority of Canadians approve of government financial support for each of the six activities. Film making received the lowest level of approval, 598, but even here, three in every five Canadians indicate approval. Museums and amateur sports receive the highest level of approval, with $84 \%$ and 837 approving, or better than four out of five...

What the table shows is that Canadians do not most strongly approve government support of those activities in which they are most likely to participate. In fact it would be truer to say the reverse... It would appear that Canadians' approval of government support for institutions depends more on their judgement of the institution's importance to Canadian culture and identity (Dixon, 1974:64). 
REFERENCES

Adam, Barry

1986 "Age, Structure, and Sexuality: Reflections on the Anthropological Evidence on Homosexual Relations" in Evelyn Blackwood, The Many Faces of Homosexuality: Anthropological Approaches to Homosexual Behavior. New York: Harrington Par's Press

Applebaum, Louis and Jasques Hebert

1982 Report of the Federal Cultural Policy Review Committee. Ottawa: Department of Communications

Bay. Ann

1974

"Getting Decent Docents". Museum News 52(7), April

Bennett, Tony et. al.

1981 Culture, Ideology and Social Process. London:

Batsford Academic and Educational Ltd.

Berland, Jody

1985 Canadian Culture and the Discourse of Cultural

Policy:Between the Devil and the Deep Blue $C$.

Peterborough: Cultural Studies Programme, Trent University

Bourdieu, Pierre and Alain Darbel, L'Amour de l'art: les

1969 musées d'art européens et leur public. Paris: Les éditions de minuit

Bottomore, Thomas

1967 "Social Stratification in Voluntary Organizations" in D.V. Glass (ed.), Social Mobility in Britain. London: Routledge Kegan Paul Ltd.

Bovey, Edmund, et. al.

1986 Funding of the Arts in Canada to the Year 2000:

Report of the Task Force on Funding of the Arts.

Ottawa: Ministry of Supply and Services

Broadland, Bob

1972

"National Museum Policy". Gazette 6(4), October

Calgary Herald, Calgary Alberta, August 12, 1988

Cameron, Duncan

1971 "The Museum, a Temple or the Forum". Curator 14(1) 


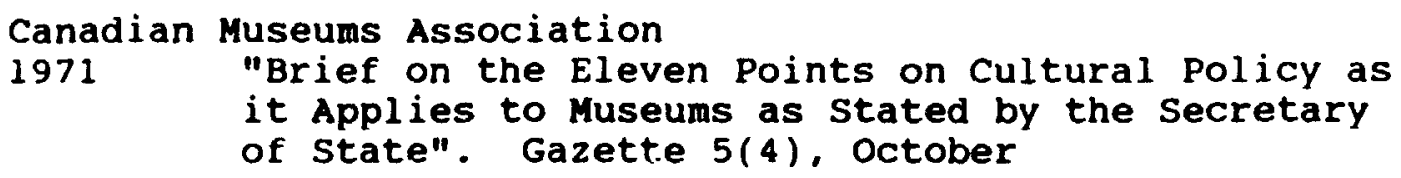

Canadian Museums Association

1983 Response to the Report of the Federal Cultural

Policy Review, Part I. Ottawa

Canadian Museums Association

1984 Response to the Report of the Federal Cultural Policy Review, Part II. Ottawa

Canadian Museums Association

1985 In Search of Financial Stability for Museums in Canada. Ottawa

Canadian Museums Association

1986 Canadian Museums Association Response to the NMC Task Force Recommendations. Ottawa

Canadian Museums Association

1988 Expansion and Innovation: Towards a New Federal Museum Policy. Ottawa

Cannizzo, Jeanne

1982

old Images / New Metaphors: The Museum in the Modern World. Toronto: Canadian Broadcasting Corporation

Cannizzo, Jeanne

1987

"How Sweet It Is: Cultural Politics in the Barbados". MUSE 4(4), winter

Collins, Zipporah $\omega$.

1981 Museums, Adults and the Humanities: A Guide for Educational Programming. Washington, D.C.: American Association of Museums

Communications Canada

1988

Challenges and Choices: Federal Policy and Program Proposals for Canadian Museums. Ottawa: Minister of Supply and Services

Cuthbertson, Shirley and Wilma Wood

1975 Planning Docent Programs. Victoria: British Columbia Provincial Museum

Department of Communications

1986

A Study Team Report to the Task Force on Program Review. Ottawa: Minister of Supply and Services 
Department of Communications

1990 Canadian Museum Policy. Ottawa: Minister of Supply and Services

Dickson, Lovat

1986 The Museum Makers: The Story of the Royal ontario Museum. Toronto: Royal Ontario Museum

Dixon, Brian, et. al.

1974 The Museum and the Canadian Public. Toronto: Culturcan Publications

Dobbs, Stephen and Elliot Eisner

1990 "Silent Pedagogy in Art Museums". Curator 33(3), September

The Edmonton Journal, Edmonton, Alberta, August 12, 1988

Ekos Research Associates

1988 Labour Market Study in the Museum Sector: Final Report. Ottawa The Gazette, Montreal, Quebec, August 12, 1988

Gever, Martha

1987 "Where We Are Now". Art in America, July, p.43-49

Gilman, B. J.

1918 Museum Ideals of Purpose and Method. Cambridge, Massachusetts: Riverside Press

Globe and Mail, Toronto, Ontario, August 12, 18, 1988

Government of Canada

1986 National Museums of Canada Task Force Discussion Guide. March

Graburn, Nelson

1977 The Museum and the Visitor Experience. Washington, D.C.: American Association of Museums

Grant, Laurence

1987 interview with Michel Cheff, Coordinator of Education at the National Gallery of Canada, Ottawa, December

Grant, Laurence

1988 interview with Susan Ditta, Curator of Film and Video at the National Gallery of Canada, November 23 
Greyson, John n.d.
"Two Men Embracing: Gay Video Images." in Video
Guide, p. 10-11

Hancocks, Anthea

1988 "Art Museums in Contempory Society". Curator $31(4)$, December

Hoskins, Alice

1979 Art Education in the Canadian Art Gallery: Guidelines for Implementing a Comprehensive Programme of Art Gallery Education. Halifax, Nova Scotia: M.A. Thesis, Nova Scotia College of Art and Design

Kelly, Robert

1985 "Museums as Status Symbols II: Attaining a state of Having Been". in R. Belk (ed.), "Advances in Non-Profit Marketing". Greenwich, Connecticut: JAI Press

International Council of Museums 1987

Statutes: Code of Professional Ethics. Paris: International Council of Museums

Kitchener-Waterloo Record, Kitchener, Ontario, August 13, 1988

Knights, Karen

n.d. "In His Own Image." Video Guide, p. 18-19

La Presse, Montreal, Quebec, August 12, 1988

Le Journal de Montreal, Montreal, Quebec, August 15, 1988

London Free Press, London, Ontario, August 12, 1988

Masse, Marcel

1990 "An Address to the Canadian Museums Association". Edmonton: June 22

Massey, vincent, et. al.

1951 Report, Royal Commission on National Development

in the Arts, Letters and Sciences. Ottawa: Edmund

cloutier, King's Printer

McAvity, John

1987

Canada's Museums: The Tourism Industry's Lost

Leader. Ottawa: Canadian Museums Association 
Media Tapes and Transcripts Ltd., 185 Sparks St., Ottawa, Ontario-Newsday, CBC/CBOT, August 11, 1988, 18:00 -Ottawa Valley Report, CJSB Radio, August 21, $1988,06: 30$

Miers, Henry A. and S. F. Markham

1932 A Report on the Museums of Canada. Edinburgh: A. Constable Lta.

Miller-Marti, Chris

1987 "Local History Museums and the creation of the

'Past'", MUSE 5(2), Summer

Ministry of Culture and Communications

$1983 a$ Community Museums Policy for Ontario. Toronto

Ministry of Culture and Communications

1983b Regulation Governing Grants to Museums. Toronto

Montreal Daily News, Montreal, Quebec, August 13, 1988

Museogramme $198815(9)$, February

National Gallery letter files, Susan Ditta, Curator of Film 1988 and Video, ottawa, Ontario,

National Gallery of Canada

1984 National Gallery Docents' Handbook. Ottawa: Education Services, National Gallery of Canada

Newsome, Barbara and Adele Silver (eds.)

1978 The Art Museum as Educator. Berkley: University of California Press

Ottawa Citizen, Ottawa, Ontario, August 11, 18, 30, 31, 1988

Pelletier, Gerard

1972 "A New Policy for Museums". Ottawa:

Gazette $6(2)$, April

Richard, clement and william withrow, et. al.

1986 Report and Recommendations of the Task Force charged with examining federal policy concerning museums. Ottawa: Department of Communications

Rush, Anita

1987 The Evolution of Federal Support to Museums and Art Galleries. Ottawa: Term Paper, Public Administration 501, Carleton University School of Public Administration 


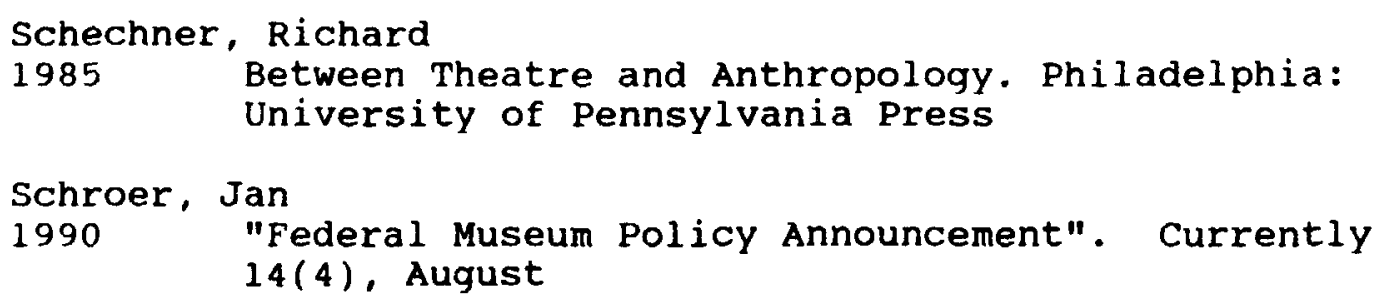

Speidel, Judithe

1978 "Feedback for Docents". The Museologist, 144 , March

Statistics Canada

1987 Survey of Heritage Institutions 1984/85. Ottawa

Sutherland, Shirley and Margaret Hohn (eds.)

1979 Docent Handbook. Vancouver, B.C.: Vancouver Museums and Planetarium

Teather, Lynne

1978 Professional Directions for Museum Work in Canada: An Analysis of Museum Jobs and Museum Studies Training Curricula. Ottawa: Canadian Museums Association

Tourism Industry Association of Canada

1989 Press Release, February

Turner, victor

1974 Dramas, Fields, and Metaphors: Symbolic Action in Human Society. Ithaca, NY: Cornell University Press

Turner, victor

1967 The Forest of Symbols: Aspects of Ndembu Ritual. Ithaca, NY: Cornell Universiy Press

Turner, Victor

1985 On the Edge of the Bush: Anthropology as

Experience. Tuscon, Arizona: University of Arizona Press

Turner, victor

1982 From Ritual to Theatre: The Human Seriousness of

Play. New York: Performing Arts Journal

Publications

Turner, Victor

1979 Process, Performance and Pilgrimage: A Study in Comparative Symbology. New Delhi: Concept

Publishing Co. 
Van Gennep, Arnold

1960 The Rites of Passage. Chicago: University of Chicago Press

van Steenburgh, Phil

1986 "Habits by YYZ, Toronto, Invitation to a Screening". Cinema Canada, July/Auqust 1986: $26-27$

Verjee, zainub

n.d. "Issues of Race". Parallelogram, 13 (3): 13-14

Williams, Raymond

1958 Culture and Society, 1780-1950. Edinburgh: Penguin Books

Winnipeg Free Press, Winnipeg, Manitoba, August 13, 1988 Wolff, Janet

The Social Production of Art. London: Macmillan 

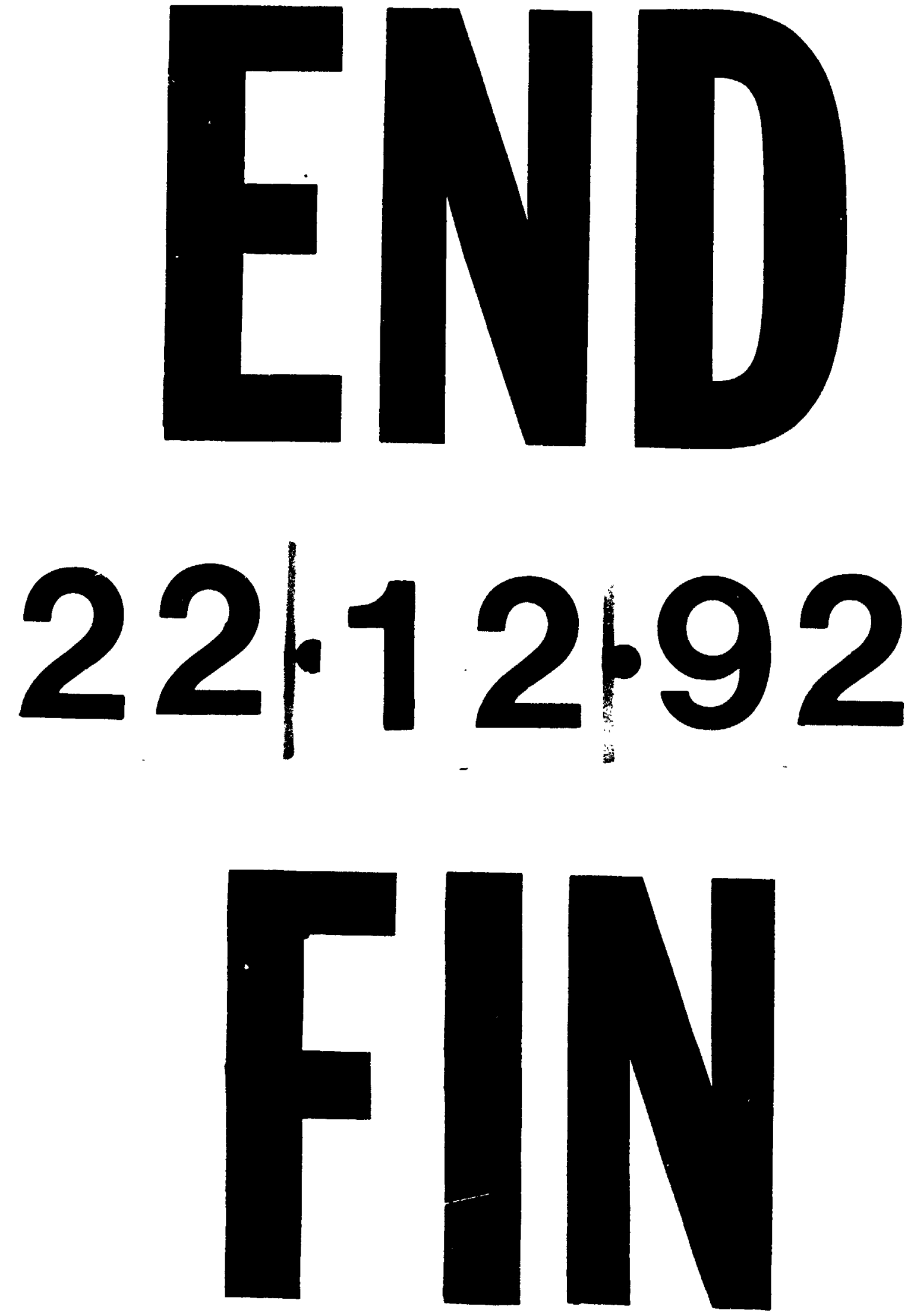